\title{
Deepwater carbonate deposition in response to re-flooding of carbonate bank and atoll-tops at glacial terminations
}

\author{
Stéphan J. Jorry ${ }^{\mathrm{a}, \mathrm{b}, *}$, André W. Droxler ${ }^{\mathrm{b}}$, Jason M. Francis ${ }^{\mathrm{b}, \mathrm{c}}$ \\ a IFREMER, Department of Marine Geosciences, BP 70, 29280 Plouzané, France \\ ${ }^{\mathrm{b}}$ Rice University, Department of Earth Science, MS126, PO Box 1892, Houston TX 77051-1892, USA \\ ${ }^{c}$ Chevron Energy Technology Company, 1500 Louisiana, Houston TX 77002-8001, USA
}

\section{A R T I C L E I N F O}

\section{Article history:}

Received 15 December 2009

Received in revised form

20 April 2010

Accepted 23 April 2010

\begin{abstract}
A B S T R A C T
The late Quaternary has experienced large glacial/interglacial climatic variations and related 10's to 100 meters high-amplitude sea level fluctuations at Milankovich frequencies from 10's to $100 \mathrm{kyr}$ during which carbonate platform tops have been exposed and re-flooded in many occasions. This study focuses on the accumulation of calci-turbidites, the aragonite onset/sharp increase in fine sediments and their timing in deep basins adjacent to carbonate platforms. A particular emphasis is developed on the occurrence of the first gravity flow event and aragonite onset/sharp increase and their linkage to the initial re-flooding of the platform tops during deglaciations. Three basins adjacent to isolated platforms in the Bahamas, the Northern Nicaragua Rise, and the Gulf of Papua, were selected to represent pure carbonate versus mixed systems, in quiescent versus tectonically active settings, and various carbonate bank top morphologies, ranging from atoll to relatively deeply and narrowly flooded flat top banks. In spite of these differences, each record illustrates a clear relationship between the timing of platform top re-flooding and initiation of significant carbonate export by gravity flows and low-density plumes into the surrounding basins. The concept of "re-flooding window" is introduced to characterize the prolific period of time during which bank and atoll-tops are flooded enough to produce large export of bank-derived aragonite and of calci-turbidites in adjacent basins. According to our datasets, the main re-flooding windows have occurred mainly on the last part of the sea level rise at each glacial termination $(T)$, those periods being marked by some of the highest rates of sea level rise. The analysis of a long-piston core from the earthquakes-prone Walton Basin (Northern Nicaragua Rise) demonstrates that sea level, not seismic activities, played a major role as trigger mechanism for the initiation of gravity flows since the last four glacial/interglacial transitions, and supports the existence of an extra glacial termination during the early portion of the transition from MIS 7.4 to MIS 7.3 (TIIIA).
\end{abstract}

(c) 2010 Elsevier Ltd. All rights reserved.

\section{Introduction}

Late Quaternary climate changes have triggered periodic largescale oscillations of sea level at glacial/interglacial transitions, during which atoll and carbonate bank-tops have been exposed and flooded. Once isolated carbonate bank and shelf tops are re-flooded during interglacial times, they become important producers of large volumes of neritic sediments (fine aragonite and magnesian calcite), excess sediment being exported by plumes (Mullins et al., 1984; Glaser and Droxler, 1993; Wilson and Roberts, 1995) and gravity flows to the adjacent deep sea (Droxler et al., 1983; Droxler and Schlager, 1985; Glaser and Droxler, 1991; Schlager et al., 1994;

\footnotetext{
* Corresponding author. IFREMER, Department of Marine Geosciences, BP 70, 29280 Plouzané, France. Tel.: +33 298224232; fax: +33 298224570.

E-mail address: stephan.jorry@ifremer.fr (S.J. Jorry).
}

Andresen et al., 2003). Previous data sets lack resolution to address the linkage between initial bank top re-flooding and first calciturbidite deposition in adjacent basins. This concept can be tested during the last glacial cycle, because sea level (eustatic) is well established for the last termination (TI) and the last glacial cycle (Yokoyama et al., 2000; Lambeck and Chappell, 2001; Alley et al., 2003; Siddall et al., 2003; Alley et al., 2005).

Observations of the last glacial cycle have clearly demonstrated for sometime that periplatform sediments accumulating on slopes and basins adjacent to carbonate platforms bear the record of sealevel fluctuations (Droxler et al., 1983; Droxler and Schlager, 1985; Schlager et al., 1994; Andresen et al., 2003; Lantzsch et al., 2007). Sea-level changes and turbidite accumulation in deep basins directly adjacent to isolated carbonate platforms are fundamentally linked to two parameters. The water depth of the bank tops and atoll lagoons is an important factor controlling the shallow water 
neritic carbonate production, which has been dramatically disturbed during late Quaternary high amplitude sea-level changes. At glacial periods, most of the carbonate platforms have been exposed and karstified (Purdy, 1974; Gischler et al., 2000; Walker et al., 2008). During interglacials, the optimum water depth for carbonate production on bank tops and atoll lagoons is intimately linked to the type of carbonate producers. Assuming that sediment production presently occurs on the shallow banks and atolls, the observed thin sediment covers and its coarse nature attest to the fact that sediments presently are not accumulating in significant quantities on platform tops to fill up the available accommodation space (Hine et al., 1988; Triffleman, 1989; Milliman et al., 1993; MacKinnon and Jones, 2001; Gischler, 2003) and the majority of the sediments are exported toward the deeper periplatform environments.

In relation to the bathymetry of carbonate bank tops and atoll lagoons, sea level amplitude is an important parameter to estimate intervals when bank tops and atoll lagoons were subaerially exposed and flooded. Sea level curves are well constrained for the last glacial cycle (Lambeck and Chappell, 2001; Lea et al., 2002; Cutler et al., 2003; Siddall et al., 2003; Thompson and Goldstein, 2005), and of better resolution for the last 20 ky (Fairbanks, 1989; Bard et al., 1990; Edwards et al., 1993; Hanebuth et al., 2000; Yokoyama et al., 2000; Camoin et al., 2004; Clark et al., 2004; Alley et al., 2005; Clark et al., 2009). However, estimating intervals of exposure becomes more difficult when the observations are older than the last glacial cycle because sea level curves past $150 \mathrm{kyr}$ are not well-constrained. In general, the details of the sea level curve for the interval prior to $130 \mathrm{kyr}$ remain elusive, primarily due to a progressive loss in the resolution of the U-series chronometer, coupled to a lack of well-preserved coral in older fossil reefs. Nevertheless, the most recent published sea level reconstructions based on stable oxygen isotope analyses of planktonic foraminifera and bulk sediments from the Red Sea reveal a strong correlation in multimillennial timescales between global sea level and Antarctic/global temperature over the past five glacial cycles (Rohling et al., 2009). Rapid sea level rise during glacial terminations occurs just after, or synchronous to, the increase in Northern Hemisphere summer insolation. These large and rapid amplitude climatic oscillations associated with glacial terminations are likely due to strong non-linearity of ice sheet dynamics during growth and decay (Cutler et al., 2003; Thompson and Goldstein, 2006; Rohling et al., 2008; Dutton et al., 2009).

In this paper, we are using the depositional frequency of calciturbidite vs. isotopic stratigraphy and mineralogy in order to evaluate the impact of platform top re-flooding on carbonate productivity and export to adjacent slopes and basins, at each glacial/interglacial transitions since the MIS 12/MIS 11 boundary. We present results based on the integration of deep-sea sediment cores collected in two different pure carbonate systems (the tectonically active zone of the Northern Nicaragua Rise and the relatively tectonically stable area of the Great Bahama Bank) and in a mixed carbonate/siliciclastic system from the Gulf of Papua.

\section{Physical settings}

\subsection{Gulf of Papua}

The Gulf of Papua, broadly defined, comprises $\sim 150,000 \mathrm{~km}^{2}$ of the northwestern Coral Sea between the southern coast of Papua New Guinea and the northeast coast of Australia (Fig. 1A). Several major rivers, most notably the Fly, drain into the Gulf of Papua on the northwest coast, delivering some 200 to 300 megatonnes per year of siliciclastic sediment to the inner shelf ((Harris et al., 1993; Milliman, 1995). In the southwest Gulf of Papua, the Great Barrier
Reef on the middle to outer shelf and several atoll systems established since the Oligocene on tectonic ridges (Tcherepanov et al., 2008) produce substantial amounts of carbonate material (Harris et al., 1993; e.g., Francis, 2007; Jorry et al., 2008). Both siliciclastic and neritic carbonate sediments are reworked from the shelf and platforms to adjacent slopes and basins of the Gulf of Papua, although at different rates depending on location (Brunskill et al., 1995; Walsh and Nittrouer, 2003; Francis, 2007; Jorry et al., 2008).

Surface waters of the Gulf of Papua lie within the latitudinal band of tropical waters characterized by relatively high temperatures of $25^{\circ}-29^{\circ} \mathrm{C}$. The surface waters of the outer shelf and Gulf of Papua basin are generally well mixed to a depth of $\sim 100 \mathrm{~m}$ and typically express normal marine salinities of $\sim 34.5-35.5 \%$ (Pickard et al., 1977; Wolanski et al., 1995). These waters are predominately brought into the Gulf of Papua by the westward flowing South Equatorial Current, producing overall convergence in the region (Wyrtki, 1962; Pickard et al., 1977). Surface circulation in the Gulf of Papua is dominated by a clockwise gyre generated under the influence the Coral Sea Coastal Current (Wolanski et al., 1995; Slingerland et al., 2008).

Several large atolls are located in the Gulf of Papua. These include the Portlock Reef partially attached to the shelf edge, and detached - isolated Ashmore, Boot, and Eastern Fields Reefs. These atolls are typical long-lived rimmed reefs (Tcherepanov et al., 2008) reaching present sea level. Their shallow lagoons have common water depths of 40-55 m (Webster, pers. com.; Jorry et al., 2008). Foraminifers, coral reefs and bryozoans are considered as dominant producers on top of Eastern Fields and Ashmore atolls. As no data is available from literature for these atolls, this assumption is based on the grain composition observed in calci-turbidites (after Jorry et al., 2008).

The central part of Pandora Trough is characterized by a very flat seafloor (Fig. 1A), bathymetry typical for an enclosed basin filled with thick siliciclastic sandy/muddy turbidites and intervening hemipelagic sediments (Jorry et al., 2008). Ashmore Trough is a SSW-NNE slope basin rimmed by active carbonate reef systems on two sides (Fig. 1A): the northern extension of the Great Barrier Reef and Ashmore, Boot, and Portlock Reefs forms to the west and the east of Ashmore Trough, respectively, two fairly continuous neritic carbonate systems (Francis et al., 2008). Surface sediment in Ashmore Trough is dominated by carbonate material ( 80 to $95 \%$ ), principally a mixture of pelagic microfossils and neritic material shed from surrounding reef systems (Carson et al., 2008; Francis et al., 2008; Muhammad et al., 2008).

\subsection{Bahamas}

With a surface area of almost $1.1 \times 10^{5} \mathrm{~km}^{2}$, the Great Bahama Bank (GBB) is the largest shallow water carbonate platform of the Bahamian archipelago with an average water depth of less than $10 \mathrm{~m}$ (e.g., Boss and Rasmussen, 1995). The GBB is positioned in the subtropical temperate climate belt, which is influenced by variations in strength and direction of the northeasterly trade winds. The North Atlantic Subtropical Gyre, which is largely wind driven, is the major source of water masses delivered to GBB (Atkinson et al., 1995; Leaman et al., 1995). Most of these surface water masses enter in the Lesser Antilles through various passages (Wajsowicz, 2002). A smaller portion (approximately 20\%) enters the Caribbean Sea through the Windward Passage between Cuba and Hispaniola (Schmitz and Richardson, 1991). A more complete synthesis about currents and oceanographic circulation of the Caribbean zone is proposed in Reijmer et al. (2009).

Tectonically, the Bahamian islands appear to be quiescent. All emergent portions of Bahamian platforms consist entirely of Late Quaternary shallow-water and aeolian carbonates (Carew and 

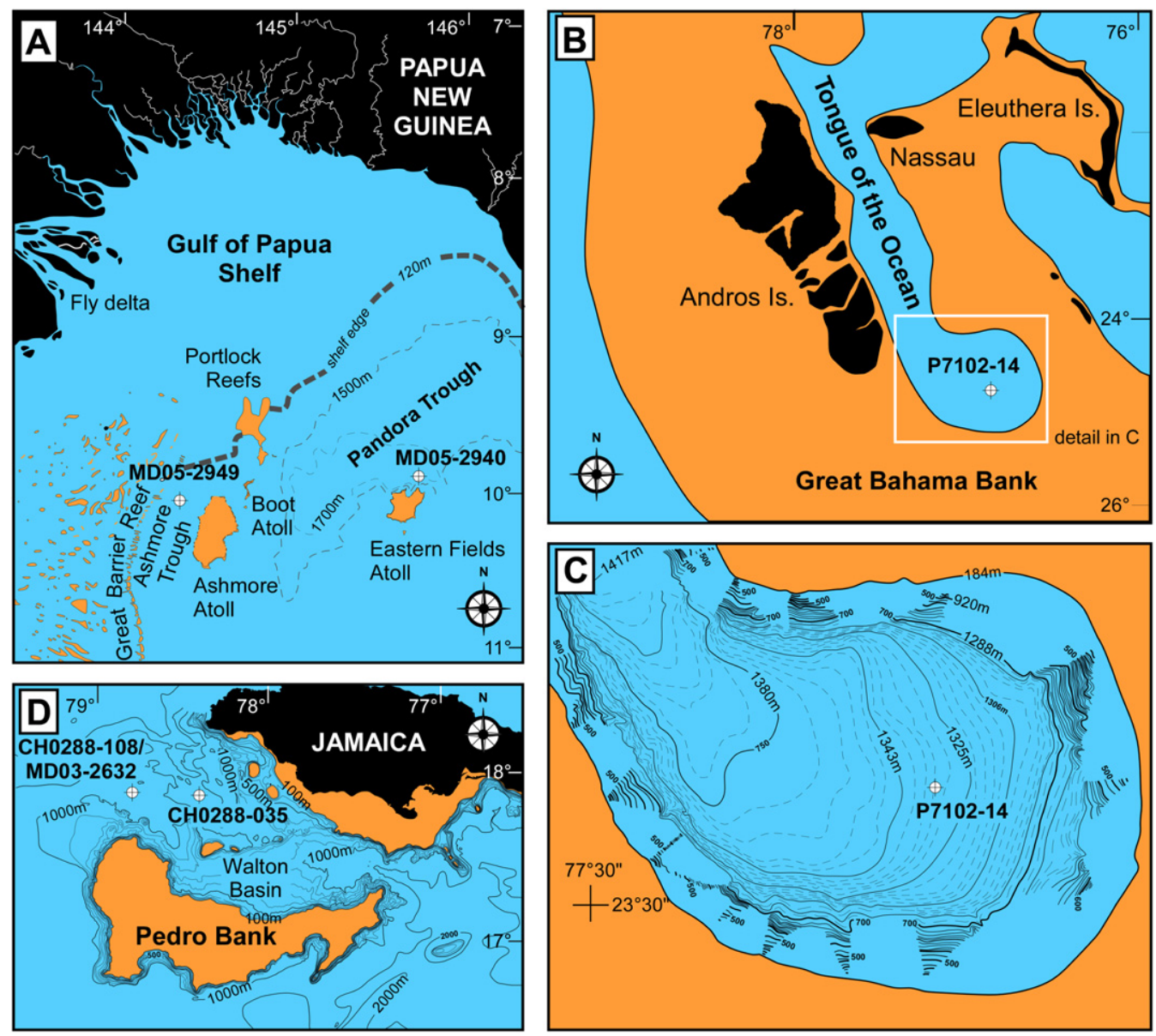

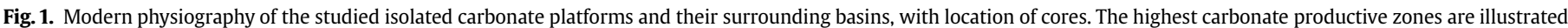

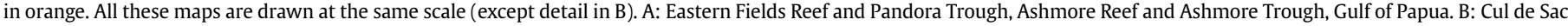

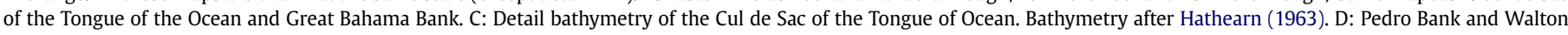
Basin, Northern Nicaragua Rise. Bathymetry after Glaser and Droxler (1991).

Mylroie, 1985; Hearty and Kindler, 1993) which show no sign of tectonically-induced deformation, although vertical failure surfaces associated with large mass-wasting events are known (Daugherty et al., 1987). Data from fossil coral reefs and flank margin caves indicate that all Bahamian banks on which there are islands have been tectonically stable, and behaving similarly, for at least the past several hundred thousand years (Carew and Mylroie, 1995).

The facies, grain-size, and mineralogy distribution patterns on GBB show a current-dominated sedimentation pattern with a clear distinction between the outer edge and the inner platform (Reijmer et al., 2009, and references herein). Skeletal (coral fragments, calcareous green algae, benthic foraminifera, gastropods, echinoderm spines and fragments, serpulids, ostracods, bryozoans, sponge spicules, and others) and non-skeletal components (peloids, ooids, grapestones, clasts) constitute the main carbonate production on top of the Great Bahama Bank (Reijmer et al., 2009). Carbonate mineralogy on GBB is well documented and shows a dominance of aragonite on the platform top with minor highmagnesium and low-magnesium calcite (Purdy, 1963; Husseini and Matthews, 1972; Milliman, 1974; Milliman et al., 1993). Aragoniterich material is produced during times, such as last interglacial (most of MIS 5) and since the last $6 \mathrm{kyr}$, when the Bahama bank tops are flooded during intervals of maximum sea level (Hine and Mullins, 1981; Milliman et al., 1993; Malone et al., 2001; Slowey et al., 2002). Platform top exposure during times of lower sea-level (e.g. MIS 4, MIS 3, MIS 2) leads to strong reduction or demise of carbonate neritic production, and almost complete cessation of neritic carbonate export towards the deep surroundings (Droxler and Schlager, 1985). Periplatform sediments that have accumulated in TOTO (a relatively flat-floored slightly tilted to the west, 1300-m-deep basin, surrounded by the wide shallow carbonate platform tops of Great Bahamas Bank, Fig. 1B and C) are excellent sediment archives recording bank top flooding and exposure and related neritic carbonate production and partial sediment export (Droxler and Schlager, 1985; Haak and Schlager, 1989).

\subsection{Northern Nicaragua Rise}

The Northern Nicaragua Rise is a $540 \mathrm{~km}$ wide, $1350 \mathrm{~km}$ long ENE-WSW oriented topographic high in the western Caribbean Sea. Extending from Honduras and Nicaragua in the west to Jamaica in the east, the Northern Nicaragua Rise consists of several shallowwater carbonate banks and shelves separated by intervening basins and channels among them the Walton Basin (Fig. 1D).

Most of the Caribbean Current flows over the Nicaragua Rise between the Caribbean shelf of Nicaragua and Honduras and the southern coast of Jamaica (Wust, 1964; Kinder et al., 1985; Hine et al., 1988). The relative strong flow results in current velocities over the banks of the Nicaragua Rise exceeding $20 \mathrm{~cm} / \mathrm{s}$ (Hallock et al., 1988). This vigor explains the occurrence of coarse sediments on the bank and shelf tops as the effect of winnowing. Thus, 
the thin Holocene sediment cover found on the bank tops results from the export of the fine (silt and mud) bank-derived sediment which is deposited from suspension on the basin slopes (Glaser and Droxler, 1991; Triffleman et al., 1992; Glaser and Droxler, 1993; Duncan et al., 1999; Sepulcre et al., 2009).

The Northern Nicaragua Rise is known as a particularly tectonically active area that results from a complex tectonic history. The Northern Nicaragua Rise is part of an island-arc originating in the East Pacific during the Cretaceous (Perfit and Heezen, 1978; Pindell and Barrett, 1990). Throughout the Paleocene to early Eocene, structural deformation and rifting was widespread along the Northern Nicaragua Rise and on Jamaica (Holcombe et al., 1990).

Perhaps the most important component in the tectonic history of this portion of the Northern Nicaragua Rise is the formation of the Cayman Trough during the early to middle Eocene (Holcombe et al., 1973; Rosencrantz and Sclater, 1986; Rosencrantz et al., 1988). Partly due to the lack of terrigenous deposition, the late Eocene to middle Miocene is believed to be a time of tectonic quiescence in Jamaica (Arden, 1975) and along the Nicaragua Rise where shallow carbonate platforms were flourishing (Cunningham, 1998; Duncan et al., 1999; Mutti et al., 2005). Final emergence of Jamaica and southward tilting of the entire Northern Nicaragua Rise is thought to have occurred during the late middle Miocene in response to major lateral movement along the Cayman Trough (Arden, 1975; Cunningham, 1998). There is evidence for continuing fault-movement and tilting of Jamaica and the NNR throughout much of the Neogene (Horsfield, 1975; Mann and Burke, 1990; Leroy et al., 1996).

The banks of the Northern Nicaragua Rise consist of nearly pure carbonate material, except near Jamaica and Central America where a large siliciclastic component has been added to the carbonate component (Arden, 1975). Algal, mollusk, sponge and foraminiferal debris with some coral fragments form the primary components of the sediment on top of banks (Zans, 1958; Dolan, 1972; Reijmer and Andresen, 2007). Hallock et al. (1988) suggest that the high concentration of nutrients in the waters passing over the Nicaragua Rise is detrimental to the growth of hermatypic corals. This explains the prominence of Halimeda on the bank and shelf tops and their upper margins. Bands of Halimeda bioherms, growing on the rims of isolated banks and shelves of the Northern Nicaragua Rise, have been frequently observed (Roberts and Murray, 1983; Hine et al., 1988; Triffleman, 1989). Dolan (1972) described Halimeda meadows on Pedro Bank.

Pedro Bank lies at the north-eastern extension of the Northern Nicaragua Rise. Contrary to the flat-topped shallow Great Bahama Bank, Pedro Bank is a northward sloping platform in which $80 \%$ of the bank lies within water depths of 20-40 meters below sea level (Zans, 1958; Triffleman et al., 1992). It can be assumed that small areas around the northern to northwestern edge of Pedro Bank (which lay in a water depth of about 60-65 meters below sea level, after Dullo (1997)) had the potential to remain flooded during periods in which sea level stood 30 to $50 \mathrm{~m}$ below present sea level (e.g. during the MIS 5 subglacial and rare times during MIS 3).

\section{Materials and methods}

Six cores (Fig. 1, Table 1) were examined in this study. One gravity core MD05-2940 and one Calypso piston core MD05-2949 were collected during a 2005 PECTEN cruise aboard R/V Marion Dufresne. Core MD05-2940 was collected in the eastern basin floor of central Pandora Trough (Gulf of Papua), in one of a series of sub-circular, partially isolated mini basins $50 \mathrm{~km}$ north of Eastern Fields reef. Core MD05-2949 was retrieved in the Ashmore Trough, a slope basin located between the Great Barrier Reef to the west and an atoll chain on its eastern border (Fig. 1). Two piston cores,
Table 1

Location, bathymetry and length of the studied cores.

\begin{tabular}{llllll}
\hline Cores & Basin & Latitude ${ }^{\circ} \mathrm{S}$ & Longitude ${ }^{\circ} \mathrm{E}$ & $\begin{array}{l}\text { Water } \\
\text { Depth } \\
(\mathrm{m})\end{array}$ & $\begin{array}{l}\text { Length } \\
(\mathrm{m})\end{array}$ \\
\hline MD05-2949 & $\begin{array}{l}\text { Ashmore } \\
\text { Trough }\end{array}$ & 10,0407 & 144,1582 & 657 & 36,6 \\
MD05-2940 & $\begin{array}{l}\text { Pandora } \\
\text { Trough }\end{array}$ & 9,7937 & 145,7248 & 1769 & 8,8 \\
CH0288-035 & Walton Basin & 17,8377 & 78,3939 & 1642 & 6 \\
CH0288-108 & Walton Basin & 17,8619 & 78,8005 & 1230 & 6,2 \\
MD03-2632 & Walton Basin & 17.8528 & 78.8107 & 1230 & 19 \\
P7102-14 & Tongue of the & 23.4020 & 76.5010 & 1330 & 7,2 \\
& Ocean & & & & \\
\hline
\end{tabular}

CH0288-035 and CH0288-108, collected during a cruise on the R/V Cape Hatteras in 1988, were collected in two flat-floored mini basins in the northern part of Walton Basin (Northern Nicaragua Rise, eastern Caribbean Sea, Fig. 1). In 2003, a CALYPSO piston core MD03-2632 was retrieved at the same location as core CH0288-108 north of Pedro Bank during a 2003 IMAGES XI - PICASSO cruise aboard R/V Marion Dufresne. A piston core P7102-14 collected in the Cul de Sac from Tongue of the Ocean (TOTO), Bahamas, in 1971 on R/V Pillsbury, was also studied (Fig. 1).

Oxygen isotopic stratigraphy of core MD05-2940 was previously established by Jorry et al. (2008). The stratigraphy of cores CHO288035 and $\mathrm{CH0288}-108$ derives from the $\delta^{18} \mathrm{O}$ curves published by Glaser (1991) and Andresen et al. (2003). For this study, oxygen isotope analyses were conducted on small batches of monospecific planktonic foraminifera that calcify in the surface mixed layer: Globigerinoides ruber for core P7102-14 (TOTO) and Globigerinoides sacculifer (without the final sac-like chamber) for cores MD05-2949 (Ashmore Trough) and MD03-2632 (Walton Basin). Samples were collected in layers composed of pelagic periplatform carbonate, purposely excluding turbidites. On average, 10 specimens were picked from the $>250 \mu \mathrm{m}$ fraction. Using a common $100 \%$ phosphoric acid bath at 90 degrees C, 20-50 $\mu$ grams of sample were reacted and analyzed using a GV Instruments Optima isotope ratio mass spectrometer at University of California, Davis. Isotope values are reported in delta notation relative to V-PDB. Repeated analyses of a marble working standard (calibrated against the international standard NBS-19) indicate an accuracy and precision of $0.05 \%(1 \sigma)$.

Six AMS dates were also obtained in cores MD05-2949 and CH0288-035 (Table 2). For each measurement, approximately 500 specimens of $G$. ruber and $G$. sacculifer were picked from the $>250 \mu \mathrm{m}$ fraction, washed in an ultrasonic bath with distilled water, and dried. These aliquots were then analyzed at the AMS laboratory at University of California, Irvine. Reported radiocarbon ages have been corrected for a marine reservoir effect of 400 years and converted to calendar years using CALIB Rev 5.0/Marine04 data set (Stuiver and Reimer, 1993; Hughen et al., 2004; Stuiver et al., 2005). We used a regional reservoir-age correction $\Delta \mathrm{R}$ of $30 \mathrm{yr}$ for core CH0288-035 (Reimer and Reimer, 2001), assuming it to be invariant with time. All ages are reported in thousands of years before present (kyr BP), where Present is defined as 1950 AD.

The $<63 \mu \mathrm{m}$ fraction of sediment was used to determine carbonate mineralogy on cores MD05-2940, MD05-2949, and CH0288-035. Carbonate mineralogy was determined on samples by $\mathrm{X}$-ray diffraction. Analyses were conducted using a Rigaku X-ray diffractometer housed at Rice University. All samples were analyzed at $2 \mathrm{kV}$ and $2 \mathrm{~mA}$ through a scan from $25^{\circ}$ to $31^{\circ}$ and a scanning speed of $0.25^{\circ}$ per minute. Peak areas for aragonite, HMC, and LMC were measured using JADE 6.1 software (Material Data Inc., Livermore, CA, USA), and used to determine their relative proportions. The aragonite proportion was determined by 
Table 2

Radiocarbon dates from cores MD05-2949, MD05-2940, CH0288-035, and P7102-14.

\begin{tabular}{|c|c|c|c|c|c|c|}
\hline Core & $\begin{array}{l}\text { Depth } \\
\text { cmbsf }\end{array}$ & Material & Laboratory number & $\begin{array}{l}{ }^{14} \mathrm{C} \text { age } \\
(\text { yrs BP) }\end{array}$ & $\begin{array}{l}\text { Calendar Age } \\
\text { (cal yrs BP) }\end{array}$ & Data origin \\
\hline MD05-2949 & 10 & G. ruber \& G. sacculifer & CAMS-18501 & $1,685 \pm 15$ & 1,283 & This study \\
\hline MD05-2949 & 140 & G. ruber E' G. sacculifer & CAMS-18501 & $7,930 \pm 25$ & 8,392 & This study \\
\hline MD05-2949 & 200 & G. ruber E G. sacculifer & CAMS-18501 & $10,980 \pm 45$ & 12,902 & This study \\
\hline MD05-2949 & 260 & G. ruber E G. sacculifer & CAMS-18501 & $23,080 \pm 120$ & 27,232 & This study \\
\hline MD05-2949 & 330 & G. ruber E G. sacculifer & CAMS-18501 & $34,090 \pm 470$ & 38,752 & This study \\
\hline MD05-2940 & 101 & G. ruber E G. sacculifer & CAMS-18501 & $9,812 \pm 20$ & 11,226 & Jorry et al., 2008 \\
\hline MD05-2940 & 181 & G. ruber E G. sacculifer & CAMS-18501 & $11,812 \pm 40$ & 13,724 & Jorry et al., 2008 \\
\hline MD05-2940 & 321 & G. ruber E G. sacculifer & CAMS-18501 & $13,022 \pm 40$ & 15,439 & Jorry et al., 2008 \\
\hline MD05-2940 & 421 & G. ruber E G. sacculifer & CAMS-18501 & $15,077 \pm 45$ & 18,436 & Jorry et al., 2008 \\
\hline MD05-2940 & 701 & G. ruber E G. sacculifer & CAMS-18501 & $18,722 \pm 60$ & 22,349 & Jorry et al., 2008 \\
\hline $\mathrm{CH} 0288-035$ & 21 & G. sacculifer & CAMS-18501 & $3975 \pm 15$ & 3,871 & This study \\
\hline P7102-14 & 78 & G. ruber & BETA-163248 & $5,730 \pm 20$ & 5,647 & Droxler, 1984 \\
\hline P7102-14 & 101,5 & G. ruber & BETA-163248 & $11,430 \pm 50$ & 12,414 & Droxler, 1984 \\
\hline
\end{tabular}

comparison to a calibration curve generated by x-ray diffraction analyses of known mixtures of research grade aragonite with coccolith calcite.

Linear sedimentation rates (LSRs) were determined in core MD05-2940 (down to $220 \mathrm{~cm}$, corresponding to the Holocene interval) and core MD05-2949 by dividing thicknesses of sediment by the time they represent. Such calculations render constant sedimentation rates between age datums, and do not account for compaction or potential hiatuses between age datums. Aragonite mass accumulation rates (MARs) were then determined by:

$\mathrm{MAR}_{\mathrm{Ar}}=\mathrm{wt} \%_{\mathrm{Ar}} \rho_{\mathrm{db}} \mathrm{LSR}$,

where wt\% Ar is the aragonite mass fraction, and $\rho_{\mathrm{db}}$ was the dry bulk density calculated by:

$\rho_{\mathrm{db}}=\rho_{\mathrm{b}}-\left(\mathrm{FP} \rho_{\text {water }}\right)$

Bulk density $\left(\rho_{\mathrm{b}}\right)$ and fractional porosity (FP) were measured by using a multisensor track system onboard the RV Marion Dufresne.

Oxygen stable isotopes, MAR Aragonite, \% of fine Aragonite, and age model are presented in Appendix 1.

\section{Results}

\subsection{Age model}

Core chronostratigraphies were established through integration of radiocarbon dating and high-resolution planktic oxygen isotope stratigraphy, and include biostratigraphic markers for cores MD05-2949 and MD03-2632 (Fig. 2). Calibrated radiocarbon dates were used as the primary age tie points over the last $\sim 43 \mathrm{kyr}$ cal BP while oxygen isotope stratigraphy was primarily used to establish the chronostratigraphy prior to this date. Distinct peaks and troughs in the oxygen isotope records were correlated to and dated with the LR04 stacked benthic oxygen isotopic record of Lisiecki and Raymo (2005) (Fig. 2).

In total, $535 \delta^{18} \mathrm{O}$ measurements on G. ruber (white) and G. sacculifer were generated and analyzed in this study (see Appendix 1). In addition to anchoring the robust chronostratigraphy, these $\delta^{18} \mathrm{O}$ data also allowed interpretation of sea-level fluctuations and marine isoptope stages (Emiliani, 1955; Shackleton and Opdyke, 1977).

Stratigraphy of core MD05-2940 was established by Jorry et al. (2008). Based on down core variations in the $\delta^{18} \mathrm{O}$ of planktic foraminifers $G$. sacculifer and on ${ }^{14} \mathrm{C}$ AMS dates, this core spans from LGM to late Holocene and records the last glacial-to-interglacial transition (Fig. 3). In core MD05-2949, the last occurrence of pink-pigmented G. ruber indicates the transition between MIS6 and MIS 5 (Thompson et al., 1979). In the lowest section of core
MD03-2632, the last occurrence of $P$. lacunosa indicates that the core reaches MIS 12 (Thierstein et al., 1977) (Fig. 2).

Stratigraphy of core $\mathrm{CH0288-35}$ includes the $\delta^{18} \mathrm{O}$ curve published by Glaser (1991) and Andresen et al. (2003). The glacialinterglacial stratigraphy of core P7102-14, initially based on the identification of aragonite-rich and aragonite-poor intervals (Droxler and Schlager, 1985), has been completed with new $\delta^{18} \mathrm{O}$ measurements on $G$. ruber (white). Both cores record the last glacial-interglacial cycle (Fig. 2).

\subsection{Lithostratigraphy}

The lower part of core MD-40 is composed of siliciclastic sandy and muddy turbidites corresponding to LGM (Jorry et al., 2008). The turbidites are separated by intervening layers rich in pelagic carbonates (hemipelagic), which become more frequent up the core. The siliciclastic turbidites disappear up the cores and are not recognized in the Holocene, which consists only of pelagic relatively carbonate-rich sediment. Once the siliciclastic sandy turbidite layers disappear in the core, $1 \mathrm{dm}$-thick calciturbidite is observed on the upper part of the core.

According to the study of Francis (2007), sediments in core MD05-2949 contain varying amounts of pelagic and neritic carbonate, as well as siliciclastic components. The fine $(<63 \mu \mathrm{m})$ size fraction consists of significant amounts of siliciclastic material, predominately quartz, feldspar, and clay minerals as well as carbonate (aragonite, high- and low-magnesium calcite). The coarse $(>63 \mu \mathrm{m})$ size fraction is dominated by pelagic carbonate particles, primarily planktic foraminifers and pteropods, with minimal benthic constituents (e.g., benthic foraminifers, ostracods, echinoderm fragments, sponge spicules).

Sediments of core P7102-14 are dominated by periplatform ooze and calci-turbidites (Droxler and Schlager, 1985; Haak and Schlager, 1989). Calci-turbidites are characterized by a sharp base, a graded bedding, parallel laminations or ripple cross laminations, a packstone or grainstone texture, and abundant shallow-water carbonate grains such as ooids, pellets, and neritic skeletal grains. Glacial sediments contain more fragments of skeletal organisms, while interglacial sediments (which include calci-turbidites) have more pellets and ooids (Haak and Schlager, 1989).

In core CH0288-035, pelagic (really periplatform) carbonate sediments primarily consist of calcitic planktonic foraminifers and coccoliths with some aragonitic pteropods tests in the coarse $(>63 \mu \mathrm{m})$ size fraction (Glaser, 1991). The fine $(>63 \mu \mathrm{m})$ size fraction is made of bank-derived aragonite and magnesian calcite, and mostly coccolith-derived low magnesian calcite. Neritic carbonate sediments in the turbidite layers consist of sand-sized skeletal particles and fragments composed of algae (Halimeda), molluscs, sponges and benthic/planktic foraminifers (Andresen et al., 2003). 


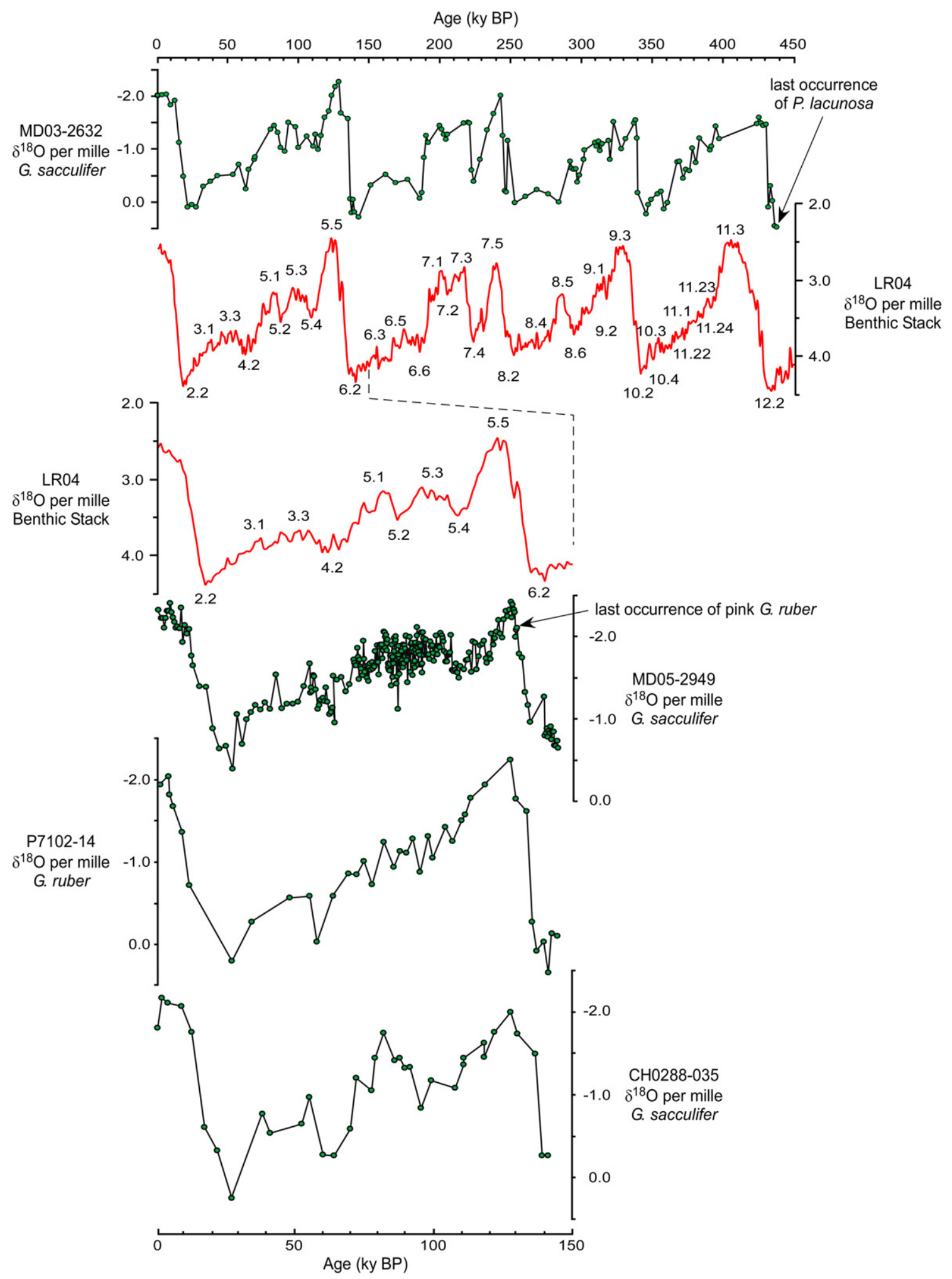

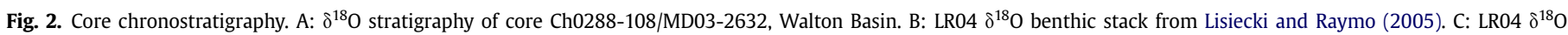

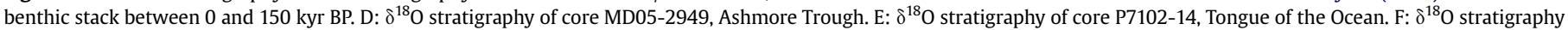
of core CH0288-035, Walton Basin.

Core CH0288-108 correlates to the upper $6 \mathrm{~m}$ of a $19 \mathrm{~m}$ long sequence recovered in core MD03-2632 (Fig. 1, Table 1) which represents approximately the last $450 \mathrm{kyr}$ (Fig. 2). The $19 \mathrm{~m}$ interval recovered in MD03-2632 alternates between fine periplatform sediments and a series of calci-turbidite layers. The fine periplatform sediment (aragonite and magnesian calcite bankderived particles) was transported from the carbonate platforms by sediment plumes that ultimately settled to the basin floor. Low magnesian calcite planktic foraminifer, pteropod, and coccolith tests settle from the upper part of the water column and 


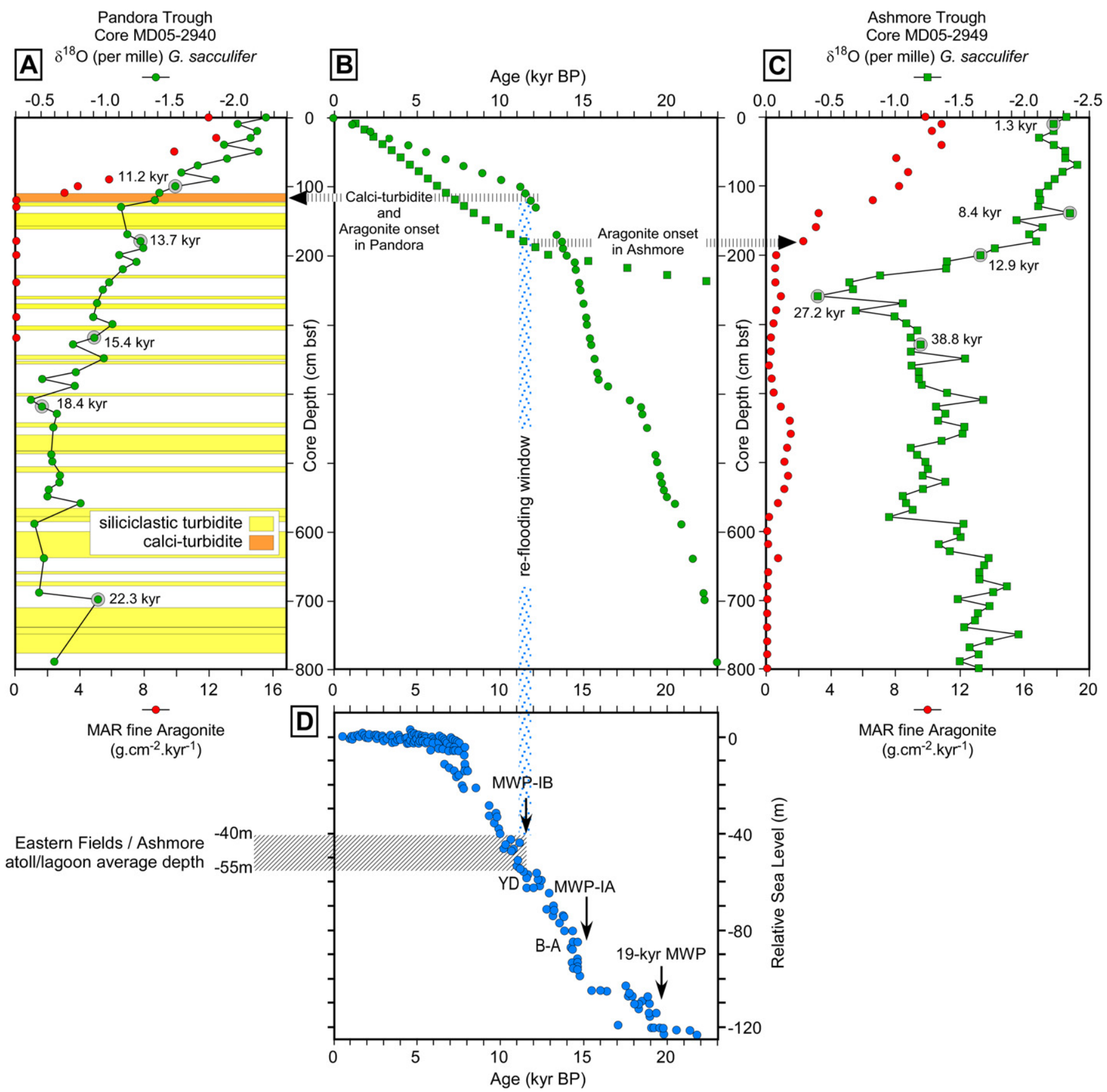

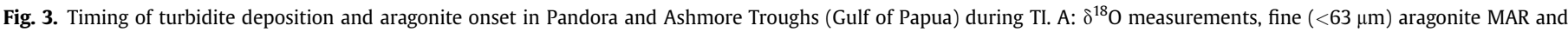

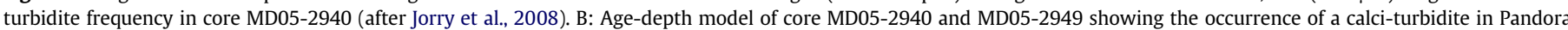

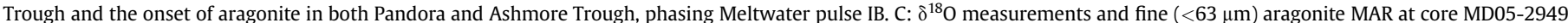

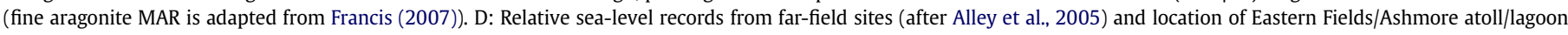
average depth. B-A is the Bølling-Allerød warming, YD is the Younger Dryas cold period, and MWP are the Meltwater pulses occurring during TI.

accumulate on the sea floor like snow. In contrast, calci-turbidites record sudden punctuated mass-flow events.

\subsection{Re-flooding of carbonate atoll-tops at TI: the example of the Gulf of Papua}

The overall deglacial trend, expressed by a relatively gradual decrease of $\delta^{18} \mathrm{O}$ values is illustrated in cores MD05-2940 and MD05-2949 (Fig. 3). However the deglacial record is clearly interrupted by a significant reversal (beginning abruptly at $\sim 12,5 \mathrm{kyr} B P$ and ending at $\sim 11,5 \mathrm{kyr} \mathrm{BP}$, Fig. 3 ), corresponding relatively well to the timing of the Younger Dryas cold period. The first warming/ deglacial step, evidenced by low $\delta^{18} \mathrm{O}$ values, corresponds most likely to the Bølling-Allerød interval during which the Meltwater pulse IA occurred (Fig. 3). The second warming/deglacial step, clearly identified by an abrupt decrease of the $\delta^{18} \mathrm{O}$, corresponds to the Meltwater pulse IB (Fig. 3). This two-step deglaciation is marked by the deposition of a calci-turbidite in MD05-2940 and in additional two Pandora Trough cores described in Jorry et al (2008). Based on ${ }^{14} \mathrm{C}$ ages, the timing of calci-turbidite deposition appears to be a synchronous event between 11,5 to $11 \mathrm{kyr}$ BP extending across Pandora Trough. 
An abrupt onset of fine aragonite is detected both in Ashmore (Francis, 2007) and Pandora Troughs (Jorry et al., 2008). Maximum aragonite MARs (up to $\sim 13 \mathrm{~g} / \mathrm{cm}^{2} \times \mathrm{kyr}$ in core MD05-2940 and $\sim 11 \mathrm{~g} / \mathrm{cm}^{2} \times \mathrm{kyr}$ in core MD05-2949) typically occur during the sea level transgression and reach a maximum during the MIS 1 highstand (Fig. 3). According to our age model, the onset of bankderived fine aragonite in both Pandora and Ashmore Troughs is contemporaneous to the deposition of a calci-turbidite in the central part of Pandora Trough during Meltwater pulse IB. Relative sea-level records from far-field sites (Alley et al., 2005) show that sea level rose at about -55 to $-40 \mathrm{~m}$ below present sea level at Meltwater pulse IB (Fig. 3). Considering that lagoon depths of Ashmore and Eastern Fields atolls are ranging between 40 and $55 \mathrm{~m}$, we conclude that the re-flooding of platform tops triggered the re-initiation of neritic carbonate production and its immediate partial export towards the adjacent slopes and basins during the sea level rise interval following the Younger Dryas (Fig. 3).

\subsection{Re-flooding of carbonate bank and atoll-tops during the last glacial/interglacial cycle}

Variation of the sedimentation in both Caribbean basins during the last glacial/interglacial cycle is well illustrated in both P7102-14 and CH0288-035 cores (Fig. 4). In the Walton Basin, thin calciturbidites have been deposited during last interglacial since Termination II (TII). These layers should coincide with the re-flooding of the majority of Pedro Bank at the end of MIS 6, when sea level rose at about $20 \mathrm{~m}$ below present-day sea level. The correspondence between both pure carbonate systems shows that the main calci-turbidite depositional trend has been initiated during the final rise of the sea level at TII (Fig. 4). The estimate of the precise timing of the first deglacial calci-turbidite is somewhat difficult due to limited resolution of the $\delta^{18} \mathrm{O}$ stratigraphy at both sites. However, we compared the ratio between the full $\delta^{18} \mathrm{O}$ amplitude from MIS 6 to MIS 5.5 and the $\delta^{18} \mathrm{O}$ value above the first deglacial calci-turbidite to approximate the relative timing of initial calci-turbidite deposition. The slightly different ratio observed in core P7102-14 (equal to 1) compared to that of core CH0288-035 (equal to 1.11) suggests that the onset of the first deglacial calciturbidite is younger in TOTO than in the Walton Basin. This observation corresponds to the shallower depth of the Great Bahama Bank (0 to $-15 \mathrm{~m}$ ) compared to that of the Pedro Bank $(-30 \mathrm{~m}$ to $-50 \mathrm{~m})$.

The precise timing of the re-flooding of isolated carbonate platforms at TII can be determined by using the high-resolution $\delta^{18} \mathrm{O}$ stratigraphy and fluctuations of the MAR aragonite in core MD05-2949 from Ashmore Trough (Figs. 1A and 5A). At TI, the onset of aragonite corresponds to the re-flooding of adjacent carbonate platforms during the Meltwater pulse IB between 11,5 and 11,0 kyr BP (Fig. 3) (Francis, 2007). Contemporaneous onset of aragonite has also been observed in three additional cores from the slope of Ashmore Trough close to the Great Barrier Reef (Francis, 2007). In focusing on TII, a good correspondence is observed between the $\delta^{18} \mathrm{O}$ and the MAR aragonite fluctuations of core MD05-2949 and changes in sea level (Fig. 5B and C). The aragonite onset is detected at about $135 \mathrm{kyr} \mathrm{BP}$ and aragonite MAR reaches a maximum between 124 and $125 \mathrm{kyr}$ BP (Francis, 2007). Between 120 and $121 \mathrm{kyr}$ BP, aragonite MAR starts to decrease progressively to reach a minimum at about $110 \mathrm{kyr}$ BP. Similar to the Meltwater pulse IB at TI, it appears that the onset of aragonite in Ashmore Trough has occurred during the last rise of the sea level at TII (Meltwater pulse IIB described by Esat et al., 1999), when sea level rose at about -55 to $-40 \mathrm{~m}$ below present sea level. It confirms that the final rise of the sea level between 130 and 136 kyr BP corresponds to a main window initiating the carbonate production on top of isolated carbonate platforms from the Bahamas, the Northern Nicaragua Rise, and the Gulf of Papua.

In spite of a shallower bathymetry at the top of the Great Bahama Bank, the return to calci-turbidite deposition at TI is observed first in the Tongue of the Ocean at about $6 \mathrm{kyr}$ BP, while we documented the first occurrence of calci-turbidite in the Walton Basin about 3,8 kyr BP (Fig. 4). In the Bahamas, the onset of fine aragonite is younger in TOTO (about $6 \mathrm{ka}$ ) than on the western margin of Great Bahama Bank where the onset has occurred at about 11 kyr BP (Droxler and Schlager, 1985; Slowey et al., 2002). This difference could be explained by the fact that the western margin of Great Bahama Bank is somewhat deeper than the central and eastern margin (Wilber et al., 1990). Concerning the Northern Nicaragua Rise, the absence of calci-turbidite deposition due the Pedro Bank-top re-flooding at the last deglaciation is observed in all cores from the Walton Basin north of Pedro Bank (CH0288-035, CH0288-108, and MD03-2632, Figs. 4 and 6). Based on a previous study, it has been demonstrated that the deposition of calciturbidites during the last deglaciation and the Holocene occurred preferentially in basins located south of the Pedro Bank (Andresen et al., 2003).

\subsection{Re-flooding of Pedro Bank during the last four glacial terminations}

The age model, based upon a reference $\delta^{18} \mathrm{O}$ stratigraphy (Lisiecki and Raymo, 2005), shows that highest sedimentation rates occurred during highstands, corresponding to the main calciturbidite depositional trends (Fig. 6B). The lowest sedimentation rates correspond to glacial stages, i.e. to periods of low sea levels and to bank-top exposures. Significant stratigraphic hiatuses are observed at TIII, TIV and TV (Fig. 6B). Erosional processes most likely induced these hiatuses during calci-turbidite deposition after bank-top re-flooding. Throughout the entire sedimentary record, the initiation of the calci-turbidites at each interglacial stage is consistent with the timing of the last four glacial terminations (TII, TIII, TIV and TV). Four corresponding re-flooding events can be defined according to a sea level high enough to flood the top of the Pedro Bank and to trigger the deposition of calci-turbidites in the Walton basin (Fig. 6B and C). The deposition of a calci-turbidite is also detected at about $225 \mathrm{kyr}$ BP. The timing of this specific gravity flow deposit nicely coincides with the recent recognition of an extra glacial termination (TIIIA) that takes place one precession cycle after TIII (Cheng et al., 2009). This Termination is bounded by the lowest and the highest insolation values in the last $400 \mathrm{kyr}$ and is coupled with a rise of the sea level from $-70 \mathrm{~m}$ to $-25 \mathrm{~m}$. The sea level rise corresponds to an important reflooding window and associated onset of carbonate production on Pedro Bank.

The analyses of Walton Basin cores illustrate that the model of highstand shedding is well defined in the last four interglacial stages. The first calci-turbidite at each interglacial occurs during each glacial termination itself, triggered by the re-flooding of the Pedro Bank-top. This study in Walton Basin, an active tectonic region of Northern Nicaragua Rise (Horsfield, 1975; Mann and Burke, 1990; Leroy et al., 1996), also demonstrates that the timing of the first calci-turbidite deposition at each glacial/interglacial transition is not controlled by earthquakes, but rather by sea-level changes facilitating bank top re-flooding and re-initiation of neritic carbonate production.

\section{Discussion}

This study confirms the strong ability of turbiditic systems to record the global late Quaternary climatic/eustatic fluctuations. Recent studies, based on high-resolution $\delta^{18} \mathrm{O}$ stratigraphies, show 


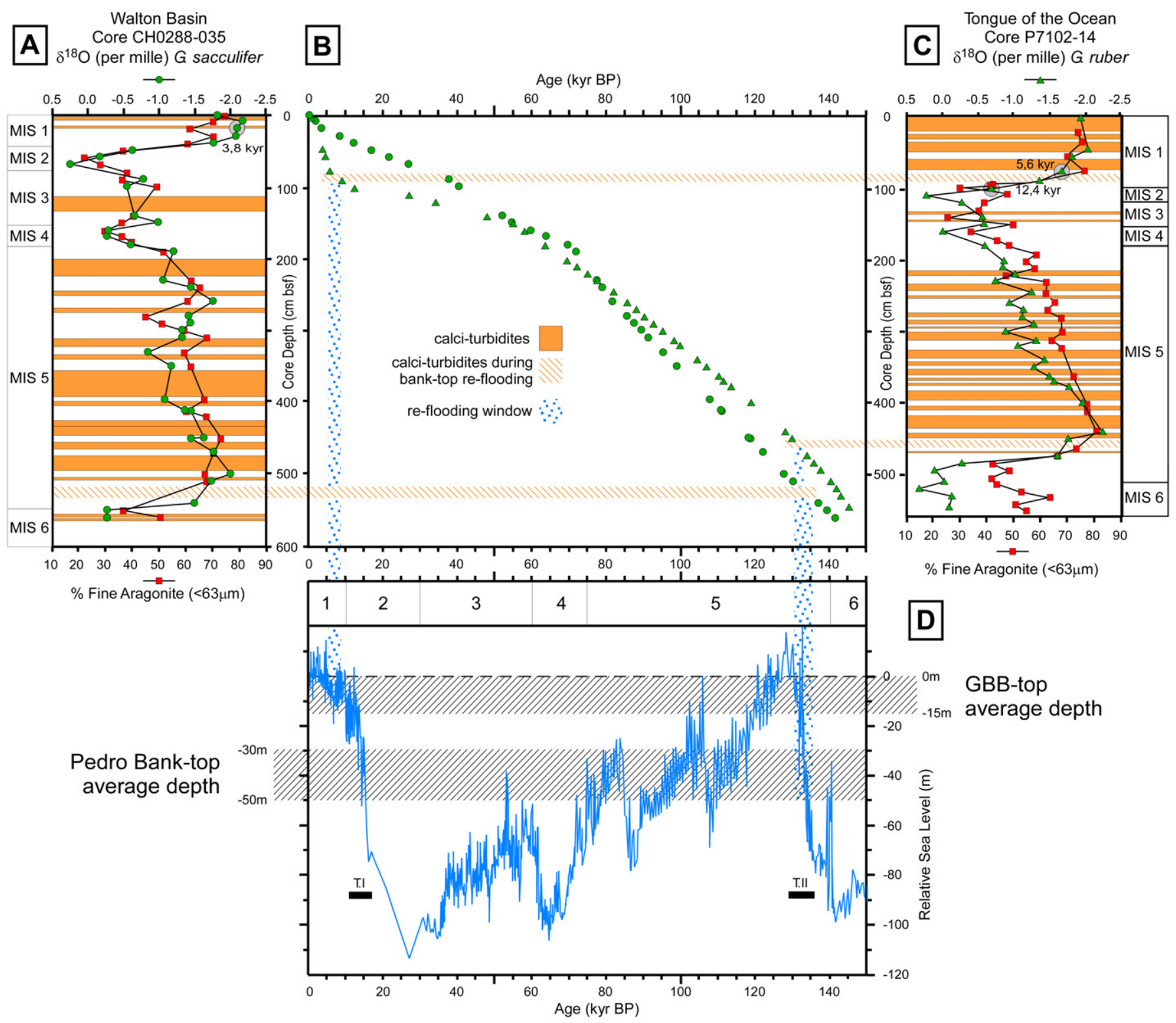

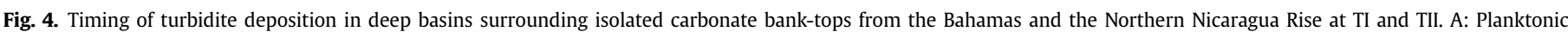

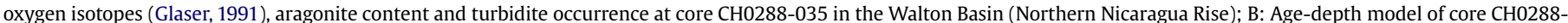

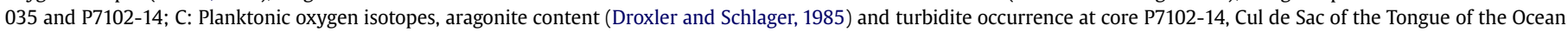

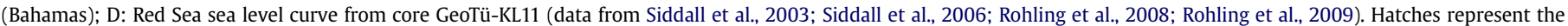
average depth of bank-tops (Pedro Bank and Great Bahama Bank [GBB]).

that climate and sea-level changes at millennial timescale have a significant influence on the deep ocean sedimentation during the last deglaciation (Skene and Piper, 2003; Jorry et al., 2008; Toucanne et al., 2008; Lebreiro et al., 2009; Pierau et al., 2010).

Re-flooding of isolated carbonate platforms at glacial/interglacial transitions and the rapid export of sediment to the deepwater demonstrate the outstanding capability for carbonate banks to produce sediment after a long period of exposure. According to our findings, it appears that intermediate high sea levels during glacial times, e.g. MIS 8.5 at $-40 \pm 20 \mathrm{~m}$ (Lea et al., 2002; Siddall et al., 2003; Bintanja et al., 2005; Rohling et al., 2009) and MIS 6.5 at $-30 \pm 20 \mathrm{~m}$ (Lea et al., 2002), had no impact on the calci-turbidite deposition in basins adjacent to the banks. The overall sedimentation rates during these events were some of the lowest, and, therefore, preclude significant carbonate production. In this context, the calci-turbidite deposited during MIS 3 (Figs. 4 and 6) would then locally illustrate that the northern deeper part of Pedro Bank (Zans, 1958; Triffleman et al., 1992; Dullo, 1997) could have been re-flooded temporarily at that time.

The initiation of the most prolific periods for sediment production on carbonate platform tops appears to be intimately linked to the occurrence of glacial terminations, in particular during the second half of these terminations and before the highest sea levels. It suggests that periods of abrupt rises of the sea level at glacial terminations appears to be a fundamental parameter controlling the carbonate production on isolated carbonate platform-tops, and then the initiation of calci-turbidite accumulation and fine aragonites in adjacent basins. According to our observations in the Gulf of Papua for TI (Fig. 3), the initiation of the carbonate production on atoll tops has occurred very rapidly during Meltwater pulse IB, a period of time corresponding to high rates of sea-level rise ( $11 \mathrm{~mm} / \mathrm{yr}$ according to Weaver et al., 2003). 

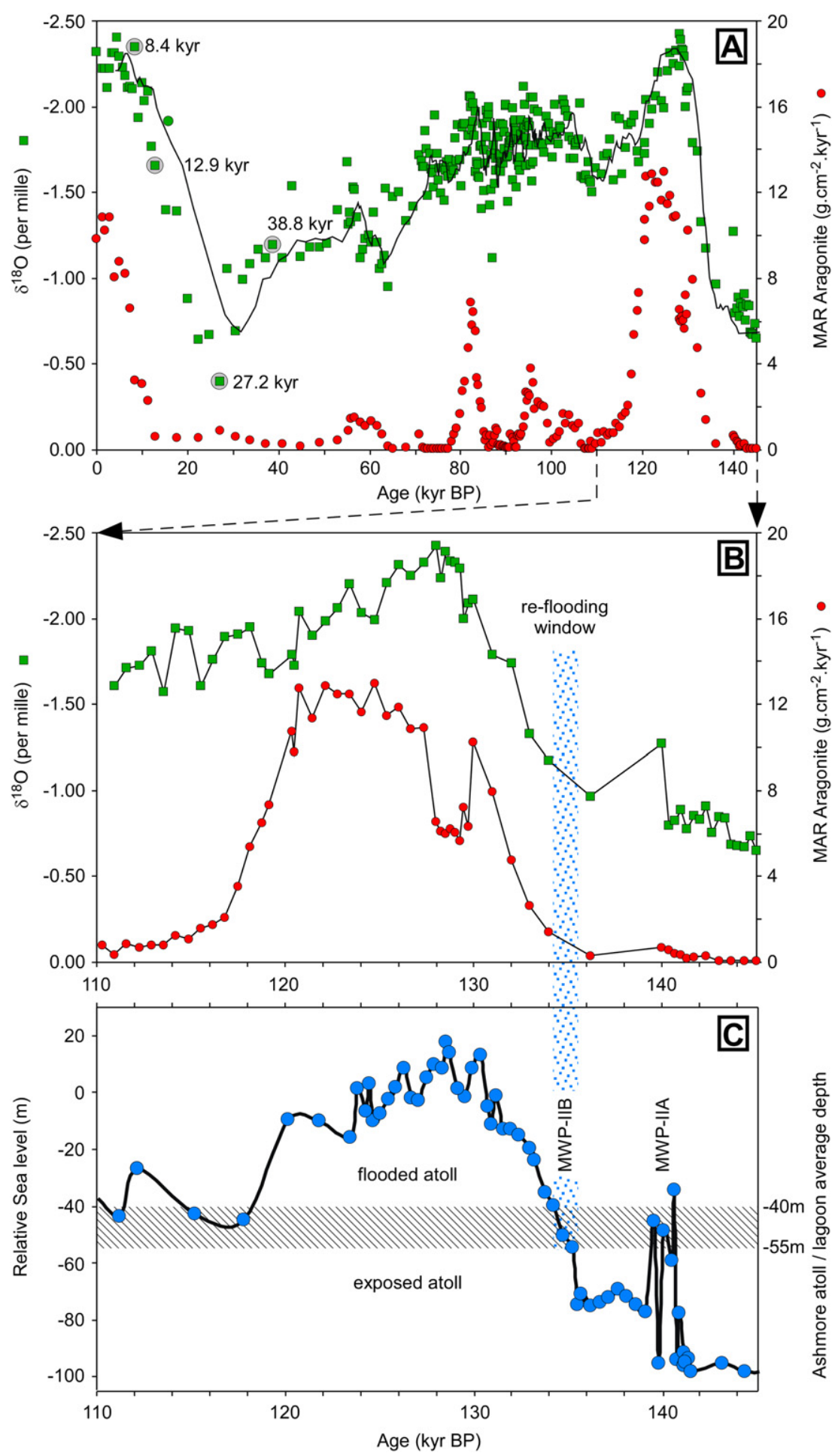

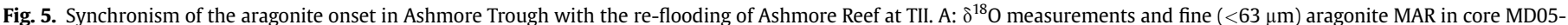

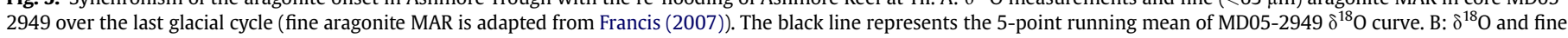

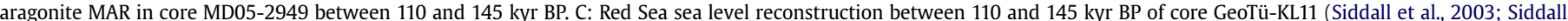
et al., 2006). Hatches represent the average depth of Ashmore atoll/lagoon. MWP are the Meltwater pulses occurring at TII (according to Esat et al., 1999).

In spite of differences in terms of rates and magnitude of sea level changes at TII (Esat et al., 1999; Siddall et al., 2006), the first deglacial calci-turbidites in TOTO and Walton Basin (Figs. 4 and 6) and the initial onset of bank-derived aragonite in Ashmore Trough (Fig. 5) occurred during the second half of TII (Meltwater pulse IIB described by Esat et al., 1999) when rates of sea level rise were very high, approximating $25 \mathrm{~mm} / \mathrm{yr}$ (Rohling et al., 2008). Our dataset doesn't support any significant influence of the first meltwater pulse at TII (Meltwater pulse IIA described by Esat et al., 1999) on the carbonate production of bank and atoll tops. Despite the absence of information concerning rates of sea-level rise at TIII, TIV and TV, a general pattern of rapid changes in sea level is 


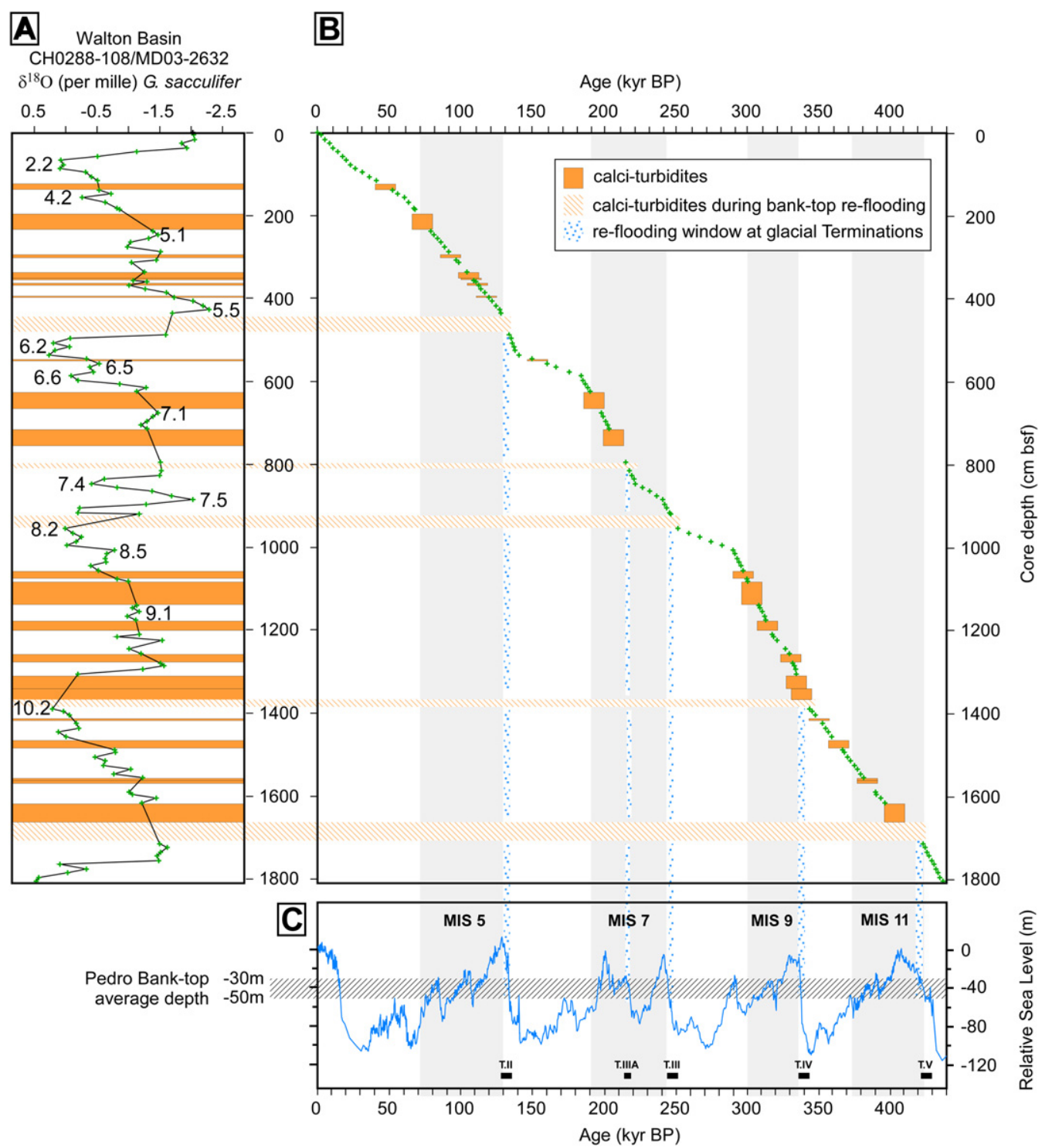

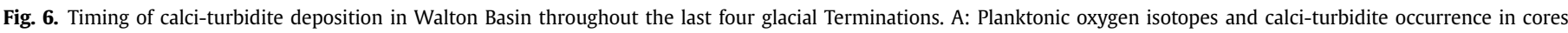

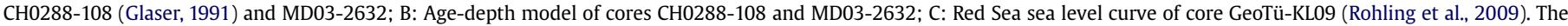
timing of TII, TIII, TIIIA, and TIV refers to Cheng et al. (2009).

expected throughout the last glacial terminations, with rates close to $10 \mathrm{~mm} / \mathrm{yr}$. This is supported by the observed $1.2 \pm 0.1 \%$ shift in $\delta^{18} \mathrm{O}_{\text {water }}$ over the last four glacial terminations (Lea et al., 2002).

The concept of "re-flooding window" is proposed for the first time in this study to characterize the very short period of time during which bank and atoll-tops are flooded at glacial terminations, reinitiating neritic carbonate production on bank and atoll tops. The timing of the re-flooding window is constrained by an optimal bathymetry on top of banks and atolls and the position of sea level during the marine incursion. The optimum bathymetry for all case studies could have been slightly different according to the type of carbonate producers. Because the most important carbonate production is observed during glacial terminations, the re-flooding window is obviously driven by the conjunction of external forcing parameters such as unusual rising of insolation, triggering the melting of glacial main ice sheets and, as a result, the rise of sea level at unusual high rates. This is confirmed by the occurrence of a calciturbidite in the Walton Basin at TIIIA (Fig. 6). This extra glacial termination, recently documented by Cheng et al. (2009), is the result of unusually low insolation that rapidly generates a large ice sheet, followed by unusually high insolation that triggers collapse. The return of the calci-turbidite deposition in the Walton Basin during TIIIA corroborates the strong relationships between glacial terminations and the carbonate production on bank and atoll-tops and immediate neritic carbonate export through plumes and gravity flows towards adjacent slopes and basins.

\section{Conclusions}

This study demonstrates that the most significant export of sediments in oceanic basins surrounding isolated carbonate platforms are driven by the combination of local and regional parameters (e.g. the bathymetry on platform top) and of external forcings (insolation variations triggering climate changes resulting in sea level fluctuations) at glacial terminations. Our findings demonstrate a clear relationship between climate, sea level, and turbiditic accumulations in several carbonate basins during the last four glacial/interglacial cycles. Each one of the case studies shows that the initiation of trends of calciturbidite and of the onset of aragonite production and basinward transport coincide with abrupt rises of the sea level at glacial 
terminations. Concerning TII, we demonstrate that the final rise of the sea level between 130 and $136 \mathrm{kyr}$ BP corresponds to a main reflooding window initiating the carbonate production on top of isolated carbonate platforms from the Bahamas, the Northern Nicaragua Rise and the Gulf of Papua. The analysis of the Walton Basin core confirms that the established highstand shedding model for calci-turbidite deposition in the last glacial/interglacial cycle is also applicable for the previous four 100-kyr cycles. This observation demonstrates that earthquakes did not play a major role as trigger mechanism for calciturbidites deposition.

\section{Acknowledgments}

We are grateful to Captains, Officers, crew members and scientific and technical shipboard parties of the PECTEN and PICASSO cruises on the $R / V$ Marion Dufresne. IPEV (Institut Polaire Français Paul-Emile Victor) is acknowledged for his support in recovering high quality cores with $R / V$ Marion Dufresne. We are grateful to Mei-Mei E. Tang and Emily Pohlman for lithology and carbonate analyses of core MD03-2532, David Winter (UC Davis) who ran oxygen isotopes analyses and Guaciara Dos Santos (University of California) for AMS radiocarbon dates. Mark Siddall, an anonymous reviewer, and Editor Colin Murray-Wallace are acknowledged for constructive comments and review. This research was supported by the Swiss National Foundation (PBGE2111250), the National Science Foundation Ocean Sciences (OCE 0305688 and OCE-8715922), and by TOTAL (R62620).

\section{Appendix}

\begin{tabular}{|c|c|c|c|c|}
\hline Core & $\begin{array}{l}\text { Depth } \\
\text { (cmbsf) }\end{array}$ & $\begin{array}{l}\delta^{18} \mathrm{O} \\
\text { (per mille) }\end{array}$ & $\begin{array}{l}\text { MAR Aragonite } \\
\left(\mathrm{g} \cdot \mathrm{cm}^{-2} \cdot \mathrm{kyr}^{-1}\right)\end{array}$ & $\begin{array}{l}\text { Calendar Age } \\
\text { (cal kyr BP) }\end{array}$ \\
\hline MD05-2940 & 0 & $-2,24$ & 11,99 & 0 \\
\hline MD05-2940 & 10 & $-2,02$ & - & 1,12 \\
\hline MD05-2940 & 20 & $-2,17$ & - & 2,24 \\
\hline MD05-2940 & 30 & $-2,12$ & 12,43 & 3,36 \\
\hline MD05-2940 & 40 & $-1,92$ & - & 4,48 \\
\hline MD05-2940 & 50 & $-2,18$ & 9,79 & 5,6 \\
\hline MD05-2940 & 60 & $-1,94$ & - & 6,72 \\
\hline MD05-2940 & 70 & $-1,71$ & - & 7,84 \\
\hline MD05-2940 & 80 & $-1,59$ & - & 8,96 \\
\hline MD05-2940 & 90 & $-1,85$ & 5,82 & 10,08 \\
\hline MD05-2940 & 101 & $-1,54$ & 3,87 & 11,2 \\
\hline MD05-2940 & 110 & $-1,41$ & 3,02 & 11,51 \\
\hline MD05-2940 & 120 & $-1,38$ & 0 & 11,82 \\
\hline MD05-2940 & 130 & $-1,12$ & 0 & 12,14 \\
\hline MD05-2940 & 170 & $-1,17$ & - & 13,39 \\
\hline MD05-2940 & 181 & $-1,27$ & 0 & 13,70 \\
\hline MD05-2940 & 190 & $-1,29$ & - & 13,80 \\
\hline MD05-2940 & 200 & $-1,11$ & 0 & 14,00 \\
\hline MD05-2940 & 210 & $-1,24$ & - & 14,50 \\
\hline MD05-2940 & 220 & $-1,13$ & - & 14,58 \\
\hline MD05-2940 & 240 & $-1,03$ & 0 & 14,75 \\
\hline MD05-2940 & 250 & $-0,98$ & - & 14,83 \\
\hline MD05-2940 & 270 & $-0,93$ & - & 14,99 \\
\hline MD05-2940 & 290 & $-0,90$ & 0 & 15,15 \\
\hline MD05-2940 & 300 & $-1,05$ & - & 15,24 \\
\hline MD05-2940 & 321 & $-0,91$ & 0 & 15,40 \\
\hline MD05-2940 & 330 & $-0,75$ & - & 15,48 \\
\hline MD05-2940 & 350 & $-0,99$ & - & 15,65 \\
\hline MD05-2940 & 370 & $-0,77$ & - & 15,81 \\
\hline MD05-2940 & 380 & $-0,51$ & - & 15,90 \\
\hline MD05-2940 & 390 & $-0,76$ & - & 16,52 \\
\hline MD05-2940 & 410 & $-0,42$ & - & 17,77 \\
\hline MD05-2940 & 421 & $-0,51$ & - & 18,40 \\
\hline MD05-2940 & 430 & $-0,62$ & - & 18,52 \\
\hline MD05-2940 & 450 & $-0,59$ & - & 18,76 \\
\hline MD05-2940 & 490 & $-0,58$ & - & 19,25 \\
\hline MD05-2940 & 500 & $-0,59$ & - & 19,37 \\
\hline MD05-2940 & 520 & $-0,66$ & - & 19,61 \\
\hline
\end{tabular}

Appendix (continued)

\begin{tabular}{|c|c|c|c|c|}
\hline Core & $\begin{array}{l}\text { Depth } \\
\text { (cmbsf) }\end{array}$ & $\begin{array}{l}\delta^{18} \mathrm{O} \\
\text { (per mille) }\end{array}$ & $\begin{array}{l}\text { MAR Aragonite } \\
\left(\mathrm{g} \cdot \mathrm{cm}^{-2} \cdot \mathrm{kyr}^{-1}\right)\end{array}$ & $\begin{array}{l}\text { Calendar Age } \\
\text { (cal kyr BP) }\end{array}$ \\
\hline MD05-2940 & 530 & $-0,64$ & - & 19,74 \\
\hline MD05-2940 & 540 & $-0,56$ & - & 19,86 \\
\hline MD05-2940 & 550 & $-0,55$ & - & 19,98 \\
\hline MD05-2940 & 560 & $-0,80$ & - & 20,50 \\
\hline MD05-2940 & 590 & $-0,45$ & - & 20,89 \\
\hline MD05-2940 & 640 & $-0,52$ & - & 21,53 \\
\hline MD05-2940 & 690 & $-0,49$ & - & 22,17 \\
\hline MD05-2940 & 701 & $-0,94$ & - & 22,30 \\
\hline MD05-2940 & 790 & $-0,60$ & - & 23,00 \\
\hline MD05-2949 & 0 & $-2,32$ & 9,81 & 0,0 \\
\hline MD05-2949 & 10 & $-2,22$ & 10,83 & 1,3 \\
\hline MD05-2949 & 20 & $-2,22$ & 10,20 & 1,8 \\
\hline MD05-2949 & 30 & $-2,11$ & - & 2,4 \\
\hline MD05-2949 & 40 & $-2,22$ & 10,87 & 2,9 \\
\hline MD05-2949 & 50 & $-2,31$ & - & 3,5 \\
\hline MD05-2949 & 60 & $-2,31$ & 8,06 & 4,0 \\
\hline MD05-2949 & 70 & $-2,40$ & - & 4,6 \\
\hline MD05-2949 & 80 & $-2,29$ & 8,78 & 5,1 \\
\hline MD05-2949 & 90 & $-2,23$ & - & 5,7 \\
\hline MD05-2949 & 100 & $-2,18$ & 8,24 & 6,2 \\
\hline MD05-2949 & 110 & $-2,11$ & - & 6,8 \\
\hline MD05-2949 & 120 & $-2,12$ & 6,59 & 7,3 \\
\hline MD05-2949 & 130 & $-2,10$ & - & 7,9 \\
\hline MD05-2949 & 140 & $-2,35$ & 3,25 & 8,4 \\
\hline MD05-2949 & 150 & $-1,93$ & - & 9,2 \\
\hline MD05-2949 & 160 & $-2,13$ & 3,05 & 9,9 \\
\hline MD05-2949 & 170 & $-2,03$ & - & 10,7 \\
\hline MD05-2949 & 180 & $-2,09$ & 2,29 & 11,4 \\
\hline MD05-2949 & 190 & $-1,77$ & - & 12,2 \\
\hline MD05-2949 & 200 & $-1,65$ & 0,61 & 12,9 \\
\hline MD05-2949 & 210 & $-1,40$ & - & 15,3 \\
\hline MD05-2949 & 220 & $-1,39$ & 0,57 & 17,7 \\
\hline MD05-2949 & 230 & $-0,88$ & - & 20,1 \\
\hline MD05-2949 & 240 & $-0,64$ & 0,58 & 22,4 \\
\hline MD05-2949 & 250 & $-0,67$ & - & 24,8 \\
\hline MD05-2949 & 260 & $-0,39$ & 0,92 & 27,2 \\
\hline MD05-2949 & 270 & $-1,05$ & - & 28,9 \\
\hline MD05-2949 & 280 & $-0,69$ & 0,63 & 30,5 \\
\hline MD05-2949 & 290 & $-0,99$ & - & 32,2 \\
\hline MD05-2949 & 300 & $-1,08$ & 0,44 & 33,8 \\
\hline MD05-2949 & 310 & $-1,17$ & - & 35,5 \\
\hline MD05-2949 & 320 & $-1,12$ & 0,30 & 37,1 \\
\hline MD05-2949 & 330 & $-1,19$ & - & 38,8 \\
\hline MD05-2949 & 340 & $-1,12$ & 0,29 & 40,8 \\
\hline MD05-2949 & 350 & $-1,53$ & - & 42,9 \\
\hline MD05-2949 & 360 & $-1,13$ & 0,18 & 44,9 \\
\hline MD05-2949 & 370 & $-1,18$ & - & 46,9 \\
\hline MD05-2949 & 380 & $-1,18$ & 0,32 & 48,9 \\
\hline MD05-2949 & 389 & $-1,20$ & - & 50,7 \\
\hline MD05-2949 & 400 & $-1,40$ & 0,42 & 53,0 \\
\hline MD05-2949 & 410 & $-1,67$ & - & 55,0 \\
\hline MD05-2949 & 420 & $-1,31$ & 0,89 & 55,3 \\
\hline MD05-2949 & 430 & $-1,38$ & - & 55,7 \\
\hline MD05-2949 & 440 & $-1,33$ & 1,48 & 56,0 \\
\hline MD05-2949 & 450 & $-1,53$ & - & 56,3 \\
\hline MD05-2949 & 460 & $-1,51$ & 1,52 & 56,7 \\
\hline MD05-2949 & 470 & $-1,35$ & - & 57,3 \\
\hline MD05-2949 & 480 & $-1,12$ & 1,28 & 57,9 \\
\hline MD05-2949 & 490 & $-1,17$ & - & 58,5 \\
\hline MD05-2949 & 500 & $-1,23$ & 1,12 & 59,1 \\
\hline MD05-2949 & 510 & $-1,25$ & - & 59,7 \\
\hline MD05-2949 & 520 & $-1,21$ & 1,33 & 60,4 \\
\hline MD05-2949 & 530 & $-1,38$ & - & 61,0 \\
\hline MD05-2949 & 540 & $-1,21$ & 1,14 & 61,6 \\
\hline MD05-2949 & 550 & $-1,06$ & - & 62,2 \\
\hline MD05-2949 & 560 & $-1,08$ & 0,75 & 62,8 \\
\hline MD05-2949 & 570 & $-1,13$ & - & 63,4 \\
\hline MD05-2949 & 580 & $-0,95$ & 0,16 & 64,0 \\
\hline MD05-2949 & 590 & $-1,52$ & - & 63,5 \\
\hline MD05-2949 & 600 & $-1,47$ & 0,07 & 65,0 \\
\hline MD05-2949 & 610 & $-1,50$ & - & 66,5 \\
\hline MD05-2949 & 620 & $-1,33$ & 0,09 & 68,0 \\
\hline MD05-2949 & 630 & $-1,42$ & - & 69,5 \\
\hline MD05-2949 & 640 & $-1,72$ & 0,75 & 71,0 \\
\hline
\end{tabular}


Appendix (continued)

\begin{tabular}{|c|c|c|c|c|}
\hline Core & $\begin{array}{l}\text { Depth } \\
\text { (cmbsf) }\end{array}$ & $\begin{array}{l}\delta^{18} \mathrm{O} \\
\text { (per mille) }\end{array}$ & $\begin{array}{l}\text { MAR Aragonite } \\
\left(\mathrm{g} \cdot \mathrm{cm}^{-2} \cdot \mathrm{kyr}^{-1}\right)\end{array}$ & $\begin{array}{l}\text { Calendar Age } \\
\text { (cal kyr BP) }\end{array}$ \\
\hline MD05-2949 & 650 & $-1,68$ & - & 71,3 \\
\hline MD05-2949 & 660 & $-1,65$ & 0,09 & 71,6 \\
\hline MD05-2949 & 670 & $-1,65$ & - & 71,9 \\
\hline MD05-2949 & 680 & $-1,86$ & 0,04 & 72,3 \\
\hline MD05-2949 & 690 & $-1,75$ & - & 72,6 \\
\hline MD05-2949 & 700 & $-1,48$ & 0,05 & 72,9 \\
\hline MD05-2949 & 710 & $-1,72$ & - & 73,2 \\
\hline MD05-2949 & 720 & $-1,64$ & 0,04 & 73,5 \\
\hline MD05-2949 & 730 & $-1,61$ & - & 73,8 \\
\hline MD05-2949 & 740 & $-1,53$ & 0,05 & 74,1 \\
\hline MD05-2949 & 750 & $-1,95$ & - & 74,5 \\
\hline MD05-2949 & 760 & $-1,73$ & 0,05 & 74,8 \\
\hline MD05-2949 & 770 & $-1,57$ & - & 75,1 \\
\hline MD05-2949 & 780 & $-1,64$ & 0,05 & 75,4 \\
\hline MD05-2949 & 790 & $-1,50$ & - & 75,7 \\
\hline MD05-2949 & 800 & $-1,64$ & 0,06 & 76,0 \\
\hline MD05-2949 & 810 & $-1,46$ & - & 76,3 \\
\hline MD05-2949 & 820 & $-1,63$ & 0,07 & 76,7 \\
\hline MD05-2949 & 830 & $-1,68$ & - & 77,0 \\
\hline MD05-2949 & 840 & $-1,59$ & 0,07 & 77,3 \\
\hline MD05-2949 & 850 & $-1,69$ & - & 77,6 \\
\hline MD05-2949 & 860 & $-1,61$ & 0,38 & 77,9 \\
\hline MD05-2949 & 870 & $-1,65$ & - & 78,2 \\
\hline MD05-2949 & 880 & $-1,63$ & 0,72 & 78,5 \\
\hline MD05-2949 & 890 & $-1,82$ & - & 78,9 \\
\hline MD05-2949 & 900 & $-1,68$ & 0,99 & 79,2 \\
\hline MD05-2949 & 910 & $-1,89$ & - & 79,5 \\
\hline MD05-2949 & 920 & $-1,69$ & 1,70 & 79,8 \\
\hline MD05-2949 & 930 & $-1,54$ & - & 80,1 \\
\hline MD05-2949 & 940 & $-1,88$ & 2,72 & 80,4 \\
\hline MD05-2949 & 950 & $-1,90$ & - & 80,7 \\
\hline MD05-2949 & 960 & $-1,90$ & 3,17 & 81,1 \\
\hline MD05-2949 & 970 & $-1,74$ & - & 81,4 \\
\hline MD05-2949 & 980 & $-1,83$ & 4,74 & 81,7 \\
\hline MD05-2949 & 990 & $-2,06$ & - & 82,0 \\
\hline MD05-2949 & 1000 & $-2,05$ & 6,88 & 82,2 \\
\hline MD05-2949 & 1010 & $-2,00$ & - & 82,4 \\
\hline MD05-2949 & 1020 & $-1,86$ & 5,82 & 82,5 \\
\hline MD05-2949 & 1030 & $-2,02$ & - & 82,7 \\
\hline MD05-2949 & 1040 & $-1,91$ & 6,40 & 82,9 \\
\hline MD05-2949 & 1050 & $-1,83$ & - & 83,1 \\
\hline MD05-2949 & 1060 & $-1,97$ & 5,52 & 83,2 \\
\hline MD05-2949 & 1070 & $-1,62$ & - & 83,4 \\
\hline MD05-2949 & 1080 & $-1,67$ & 3,36 & 83,6 \\
\hline MD05-2949 & 1090 & $-1,60$ & - & 83,8 \\
\hline MD05-2949 & 1100 & $-1,66$ & 3,04 & 84,0 \\
\hline MD05-2949 & 1110 & $-1,59$ & - & 84,1 \\
\hline MD05-2949 & 1120 & $-1,77$ & 2,21 & 84,3 \\
\hline MD05-2949 & 1130 & $-1,40$ & - & 84,5 \\
\hline MD05-2949 & 1140 & $-1,77$ & 1,97 & 84,7 \\
\hline MD05-2949 & 1150 & $-1,90$ & - & 84,9 \\
\hline MD05-2949 & 1160 & $-1,75$ & 0,84 & 85,0 \\
\hline MD05-2949 & 1170 & $-1,51$ & - & 85,2 \\
\hline MD05-2949 & 1180 & $-1,67$ & 0,44 & 85,4 \\
\hline MD05-2949 & 1190 & $-1,82$ & - & 85,6 \\
\hline MD05-2949 & 1200 & $-1,98$ & 0,66 & 85,7 \\
\hline MD05-2949 & 1210 & $-1,93$ & - & 85,9 \\
\hline MD05-2949 & 1220 & $-1,96$ & 0,14 & 86,1 \\
\hline MD05-2949 & 1230 & $-2,00$ & - & 86,3 \\
\hline MD05-2949 & 1240 & $-1,43$ & 0,66 & 86,5 \\
\hline MD05-2949 & 1250 & $-1,51$ & - & 86,6 \\
\hline MD05-2949 & 1260 & $-1,72$ & 0,22 & 86,8 \\
\hline MD05-2949 & 1270 & $-1,12$ & - & 87,0 \\
\hline MD05-2949 & 1280 & $-1,89$ & 0,32 & 87,2 \\
\hline MD05-2949 & 1290 & $-1,77$ & - & 87,3 \\
\hline MD05-2949 & 1300 & $-1,55$ & 0,67 & 87,5 \\
\hline MD05-2949 & 1310 & $-1,73$ & - & 87,6 \\
\hline MD05-2949 & 1320 & $-1,63$ & 1,03 & 87,8 \\
\hline MD05-2949 & 1330 & $-1,70$ & - & 87,9 \\
\hline MD05-2949 & 1340 & $-1,82$ & 0,92 & 88,1 \\
\hline MD05-2949 & 1350 & $-1,70$ & - & 88,2 \\
\hline MD05-2949 & 1360 & $-1,82$ & 0,21 & 88,4 \\
\hline MD05-2949 & 1370 & $-1,64$ & - & 88,5 \\
\hline MD05-2949 & 1380 & $-1,71$ & 0,18 & 88,7 \\
\hline
\end{tabular}

Appendix (continued)

\begin{tabular}{|c|c|c|c|c|}
\hline Core & $\begin{array}{l}\text { Depth } \\
\text { (cmbsf) }\end{array}$ & $\begin{array}{l}\delta^{18} \mathrm{O} \\
\text { (per mille) }\end{array}$ & $\begin{array}{l}\text { MAR Aragonite } \\
\left(\mathrm{g} \cdot \mathrm{cm}^{-2} \cdot \mathrm{kyr}^{-1}\right)\end{array}$ & $\begin{array}{l}\text { Calendar Age } \\
\text { (cal kyr BP) }\end{array}$ \\
\hline MD05-2949 & 1390 & $-1,62$ & - & 88,8 \\
\hline MD05-2949 & 1400 & $-1,90$ & 0,20 & 89,0 \\
\hline MD05-2949 & 1410 & $-1,68$ & - & 89,1 \\
\hline MD05-2949 & 1420 & $-1,67$ & 0,15 & 89,3 \\
\hline MD05-2949 & 1430 & $-1,89$ & - & 89,4 \\
\hline MD05-2949 & 1440 & $-1,85$ & 0,14 & 89,6 \\
\hline MD05-2949 & 1450 & $-1,76$ & - & 89,7 \\
\hline MD05-2949 & 1460 & $-2,01$ & 0,13 & 89,9 \\
\hline MD05-2949 & 1470 & $-2,01$ & - & 90,0 \\
\hline MD05-2949 & 1480 & $-1,71$ & 0,10 & 90,2 \\
\hline MD05-2949 & 1490 & $-1,71$ & - & 90,3 \\
\hline MD05-2949 & 1500 & $-1,44$ & 0,10 & 90,5 \\
\hline MD05-2949 & 1510 & $-1,77$ & - & 90,6 \\
\hline MD05-2949 & 1520 & $-1,79$ & 0,11 & 90,8 \\
\hline MD05-2949 & 1530 & $-1,79$ & - & 90,9 \\
\hline MD05-2949 & 1540 & $-1,82$ & 0,72 & 91,1 \\
\hline MD05-2949 & 1550 & $-1,80$ & - & 91,2 \\
\hline MD05-2949 & 1560 & $-1,99$ & 0,58 & 91,4 \\
\hline MD05-2949 & 1570 & $-1,57$ & - & 91,5 \\
\hline MD05-2949 & 1580 & $-1,82$ & 0,40 & 91,7 \\
\hline MD05-2949 & 1590 & $-1,91$ & - & 91,8 \\
\hline MD05-2949 & 1600 & $-1,92$ & 0,10 & 92,0 \\
\hline MD05-2949 & 1610 & $-1,82$ & - & 92,1 \\
\hline MD05-2949 & 1620 & $-1,86$ & 0,14 & 92,3 \\
\hline MD05-2949 & 1630 & $-1,53$ & - & 92,4 \\
\hline MD05-2949 & 1640 & $-1,69$ & 0,65 & 92,6 \\
\hline MD05-2949 & 1650 & $-1,65$ & - & 92,7 \\
\hline MD05-2949 & 1660 & $-1,81$ & 0,75 & 92,9 \\
\hline MD05-2949 & 1670 & $-1,70$ & - & 93,0 \\
\hline MD05-2949 & 1680 & $-1,63$ & 0,61 & 93,2 \\
\hline MD05-2949 & 1690 & $-1,83$ & - & 93,3 \\
\hline MD05-2949 & 1700 & $-1,92$ & 0,75 & 93,5 \\
\hline MD05-2949 & 1710 & $-1,80$ & - & 93,6 \\
\hline MD05-2949 & 1720 & $-1,88$ & 1,07 & 93,8 \\
\hline MD05-2949 & 1730 & $-2,11$ & - & 93,9 \\
\hline MD05-2949 & 1740 & $-2,01$ & 1,56 & 94,1 \\
\hline MD05-2949 & 1750 & $-1,87$ & - & 94,2 \\
\hline MD05-2949 & 1760 & $-1,66$ & 2,70 & 94,4 \\
\hline MD05-2949 & 1770 & $-1,82$ & - & 94,5 \\
\hline MD05-2949 & 1780 & $-1,89$ & 2,28 & 94,7 \\
\hline MD05-2949 & 1790 & $-1,91$ & - & 94,8 \\
\hline MD05-2949 & 1800 & $-1,77$ & 2,64 & 95,0 \\
\hline MD05-2949 & 1810 & $-1,89$ & - & 95,1 \\
\hline MD05-2949 & 1820 & $-1,89$ & 2,54 & 95,3 \\
\hline MD05-2949 & 1830 & $-1,66$ & - & 95,4 \\
\hline MD05-2949 & 1840 & $-2,05$ & 3,82 & 95,6 \\
\hline MD05-2949 & 1850 & $-1,56$ & - & 95,7 \\
\hline MD05-2949 & 1860 & $-1,67$ & 3,12 & 95,9 \\
\hline MD05-2949 & 1870 & $-2,05$ & - & 96,0 \\
\hline MD05-2949 & 1880 & $-1,98$ & 1,90 & 96,3 \\
\hline MD05-2949 & 1890 & $-1,77$ & - & 96,7 \\
\hline MD05-2949 & 1900 & $-1,97$ & 2,21 & 97,0 \\
\hline MD05-2949 & 1910 & $-1,79$ & - & 97,4 \\
\hline MD05-2949 & 1920 & $-1,78$ & 2,04 & 97,7 \\
\hline MD05-2949 & 1930 & $-1,78$ & - & 98,1 \\
\hline MD05-2949 & 1940 & $-1,73$ & 2,03 & 98,4 \\
\hline MD05-2949 & 1950 & $-1,94$ & - & 98,7 \\
\hline MD05-2949 & 1960 & $-1,88$ & 1,20 & 99,1 \\
\hline MD05-2949 & 1970 & $-1,90$ & - & 99,4 \\
\hline MD05-2949 & 1980 & $-1,80$ & 0,36 & 99,8 \\
\hline MD05-2949 & 1990 & $-1,71$ & - & 100,1 \\
\hline MD05-2949 & 2000 & $-1,85$ & 0,49 & 100,4 \\
\hline MD05-2949 & 2010 & $-2,01$ & - & 100,8 \\
\hline MD05-2949 & 2020 & $-1,84$ & 0,62 & 101,1 \\
\hline MD05-2949 & 2030 & $-1,78$ & - & 101,5 \\
\hline MD05-2949 & 2040 & $-1,89$ & 0,82 & 101,8 \\
\hline MD05-2949 & 2050 & $-1,87$ & - & 102,2 \\
\hline MD05-2949 & 2060 & $-2,04$ & 1,67 & 102,5 \\
\hline MD05-2949 & 2070 & $-2,01$ & - & 102,8 \\
\hline MD05-2949 & 2080 & $-1,98$ & 1,25 & 103,2 \\
\hline MD05-2949 & 2090 & $-1,94$ & - & 103,5 \\
\hline MD05-2949 & 2100 & $-1,83$ & 1,60 & 103,9 \\
\hline MD05-2949 & 2110 & $-1,70$ & - & 104,2 \\
\hline MD05-2949 & 2120 & $-1,80$ & 1,14 & 104,6 \\
\hline
\end{tabular}


Appendix (continued)

\begin{tabular}{|c|c|c|c|c|}
\hline Core & $\begin{array}{l}\text { Depth } \\
\text { (cmbsf) }\end{array}$ & $\begin{array}{l}\delta^{18} \mathrm{O} \\
\text { (per mille) }\end{array}$ & $\begin{array}{l}\text { MAR Aragonite } \\
\left(\mathrm{g} \cdot \mathrm{cm}^{-2} \cdot \mathrm{kyr}^{-1}\right)\end{array}$ & $\begin{array}{l}\text { Calendar Age } \\
\text { (cal kyr BP) }\end{array}$ \\
\hline MD05-2949 & 2130 & $-1,70$ & - & 104,9 \\
\hline MD05-2949 & 2140 & $-1,77$ & 0,99 & 105,2 \\
\hline MD05-2949 & 2150 & $-1,79$ & - & 105,6 \\
\hline MD05-2949 & 2160 & $-1,81$ & 1,25 & 105,9 \\
\hline MD05-2949 & 2170 & $-2,02$ & - & 106,3 \\
\hline MD05-2949 & 2180 & $-1,59$ & 0,28 & 106,6 \\
\hline MD05-2949 & 2190 & $-1,59$ & - & 106,9 \\
\hline MD05-2949 & 2200 & $-1,58$ & 0,06 & 107,3 \\
\hline MD05-2949 & 2210 & $-1,60$ & 0,06 & 107,6 \\
\hline MD05-2949 & 2220 & $-1,67$ & 0,06 & 108,0 \\
\hline MD05-2949 & 2230 & $-1,57$ & 0,07 & 108,3 \\
\hline MD05-2949 & 2240 & $-1,56$ & 0,42 & 108,7 \\
\hline MD05-2949 & 2250 & $-1,50$ & 0,04 & 109,0 \\
\hline MD05-2949 & 2260 & $-1,64$ & 0,26 & 109,7 \\
\hline MD05-2949 & 2270 & - & 0,79 & 110,3 \\
\hline MD05-2949 & 2280 & $-1,60$ & 0,35 & 111,0 \\
\hline MD05-2949 & 2290 & $-1,71$ & 0,83 & 111,6 \\
\hline MD05-2949 & 2300 & $-1,72$ & 0,68 & 112,3 \\
\hline MD05-2949 & 2310 & $-1,81$ & 0,80 & 112,9 \\
\hline MD05-2949 & 2320 & $-1,57$ & 0,78 & 113,6 \\
\hline MD05-2949 & 2330 & $-1,94$ & 1,24 & 114,2 \\
\hline MD05-2949 & 2340 & $-1,93$ & 1,04 & 114,9 \\
\hline MD05-2949 & 2350 & $-1,60$ & 1,59 & 115,5 \\
\hline MD05-2949 & 2360 & $-1,76$ & 1,71 & 116,2 \\
\hline MD05-2949 & 2370 & $-1,89$ & 2,08 & 116,8 \\
\hline MD05-2949 & 2380 & $-1,91$ & 3,54 & 117,5 \\
\hline MD05-2949 & 2390 & $-1,95$ & 5,36 & 118,1 \\
\hline MD05-2949 & 2400 & $-1,74$ & 6,50 & 118,8 \\
\hline MD05-2949 & 2406 & $-1,68$ & 7,33 & 119,2 \\
\hline MD05-2949 & 2424 & $-1,79$ & 10,73 & 120,4 \\
\hline MD05-2949 & 2426 & $-1,73$ & 9,77 & 120,5 \\
\hline MD05-2949 & 2430 & $-2,04$ & 12,74 & 120,8 \\
\hline MD05-2949 & 2441 & $-1,90$ & 11,34 & 121,5 \\
\hline MD05-2949 & 2451 & $-1,98$ & 12,83 & 122,1 \\
\hline MD05-2949 & 2461 & $-2,06$ & 12,46 & 122,8 \\
\hline MD05-2949 & 2471 & $-2,20$ & 12,46 & 123,4 \\
\hline MD05-2949 & 2481 & $-2,04$ & 11,61 & 124,1 \\
\hline MD05-2949 & 2491 & $-1,99$ & 12,98 & 124,7 \\
\hline MD05-2949 & 2501 & $-2,21$ & 11,44 & 125,4 \\
\hline MD05-2949 & 2511 & $-2,31$ & 11,82 & 126,0 \\
\hline MD05-2949 & 2521 & $-2,25$ & 10,81 & 126,7 \\
\hline MD05-2949 & 2531 & $-2,32$ & 10,91 & 127,3 \\
\hline MD05-2949 & 2541 & $-2,42$ & 6,54 & 128,0 \\
\hline MD05-2949 & 2551 & $-2,23$ & 6,11 & 128,3 \\
\hline MD05-2949 & 2561 & $-2,39$ & 5,95 & 128,5 \\
\hline MD05-2949 & 2571 & $-2,34$ & 6,21 & 128,8 \\
\hline MD05-2949 & 2581 & $-2,32$ & 6,03 & 129,0 \\
\hline MD05-2949 & 2591 & $-2,29$ & 5,66 & 129,3 \\
\hline MD05-2949 & 2601 & $-2,00$ & 7,21 & 129,5 \\
\hline MD05-2949 & 2611 & $-2,08$ & 6,31 & 129,8 \\
\hline MD05-2949 & 2621 & $-2,11$ & 10,21 & 130,0 \\
\hline MD05-2949 & 2631 & $-1,79$ & 7,91 & 131,0 \\
\hline MD05-2949 & 2641 & $-1,74$ & 4,73 & 132,0 \\
\hline MD05-2949 & 2651 & $-1,32$ & 2,62 & 133,0 \\
\hline MD05-2949 & 2661 & $-1,17$ & 1,41 & 134,0 \\
\hline MD05-2949 & 2671 & $-0,96$ & 0,25 & 135,0 \\
\hline MD05-2949 & 2681 & $-1,27$ & 0,69 & 140,0 \\
\hline MD05-2949 & 2691 & $-0,79$ & 0,58 & 140,3 \\
\hline MD05-2949 & 2701 & $-0,83$ & 0,40 & 140,7 \\
\hline MD05-2949 & 2711 & $-0,88$ & 0,32 & 141,0 \\
\hline MD05-2949 & 2721 & $-0,78$ & 0,19 & 141,3 \\
\hline MD05-2949 & 2731 & $-0,85$ & 0,23 & 141,7 \\
\hline MD05-2949 & 2741 & $-0,83$ & - & 142,0 \\
\hline MD05-2949 & 2751 & $-0,91$ & 0,26 & 142,3 \\
\hline MD05-2949 & 2761 & $-0,75$ & - & 142,7 \\
\hline MD05-2949 & 2771 & $-0,85$ & 0,06 & 143,0 \\
\hline MD05-2949 & 2781 & $-0,84$ & - & 143,3 \\
\hline MD05-2949 & 2791 & $-0,68$ & 0,07 & 143,7 \\
\hline MD05-2949 & 2801 & $-0,68$ & - & 144,0 \\
\hline MD05-2949 & 2811 & $-0,67$ & 0,07 & 144,3 \\
\hline MD05-2949 & 2821 & $-0,73$ & - & 144,7 \\
\hline MD05-2949 & 2831 & $-0,65$ & 0,04 & 145,0 \\
\hline CH0288-035 & 0 & $-1,81$ & 74,0 & 0,0 \\
\hline CH0288-035 & 8 & $-2,17$ & 70,1 & 1,7 \\
\hline
\end{tabular}

Appendix (continued)

\begin{tabular}{lcllc}
\hline Core & $\begin{array}{l}\text { Depth } \\
\text { (cmbsf) }\end{array}$ & $\begin{array}{l}\delta^{18} \mathrm{O} \\
\text { (per mille) }\end{array}$ & $\begin{array}{l}\text { MAR Aragonite } \\
\left(\mathrm{g}_{\mathrm{cm}} \mathrm{cm}^{-2} \cdot \mathrm{kyr}^{-1}\right)\end{array}$ & $\begin{array}{l}\text { Calendar Age } \\
(\text { cal kyr BP) }\end{array}$ \\
\hline CH0288-035 & 21 & $-2,11$ & 61,5 & 3,9 \\
CH0288-035 & 30 & $-2,07$ & 70,1 & 8,6 \\
CH0288-035 & 39 & $-1,76$ & 60,4 & 12,2 \\
CH0288-035 & 49 & $-0,61$ & 36,2 & 17,0 \\
CH0288-035 & 58 & $-0,33$ & 22,4 & 21,7 \\
CH0288-035 & 68 & 0,25 & 27,9 & 27,0 \\
CH0288-035 & 79 & - & 38,0 & 32,8 \\
CH0288-035 & 89 & $-0,77$ & 37,1 & 38,0 \\
CH0288-035 & 99 & $-0,54$ & 49,3 & 40,9 \\
CH0288-035 & 139 & $-0,65$ & 41,2 & 52,4 \\
CH0288-035 & 148 & $-0,97$ & 36,0 & 55,0
\end{tabular}

CH0288-035

CH0288-035

CH0288-035

CH0288-035

$\mathrm{CH} 0288-035$

CH0288-035

CH0288-035

$\mathrm{CH} 0288-035$

CH0288-035

CH0288-035

$\mathrm{CH} 0288-035$

CH0288-035

CH0288-035

CH0288-035

CH0288-035

CH0288-035

CH0288-035

CH0288-035

CH0288-035

CH0288-035

CH0288-035

CH0288-035

CH0288-035

CH0288-035

CH0288-035

P7102-14

P7102-14

P7102-14

P7102-14

P7102-14

P7102-14

P7102-14

P7102-14

P7102-14

P7102-14

P7102-14

P7102-14

P7102-14

P7102-14

P7102-14

P7102-14

P7102-14

P7102-14

P7102-14

P7102-14

P7102-14

P7102-14

P7102-14

P7102-14

P7102-14

P7102-14

P7102-14

P7102-14

P7102-14

P7102-14

P7102-14

P7102-14

P7102-14

P7102-14

P7102-14

P7102-14

P7102-14

P7102-14

P7102-14
148

160
168

$180-0,59$

$189-1,20$

$229-1,05$

$238-1,44$

$259-1,75$

$279-1,41$

$298-1,32$

$308-1,33$

$329-0,84$

$348-1,17$

$394-1,08$

$409-1,36$

$410-1,44$

$447-1,62$

$448-1,45$

$467-1,76$

$497-2,00$

$508-1,73$

$548-0,27$

$558-0,27$

$3,5-1,93$

$21-$

$\begin{aligned} 35 & -\end{aligned}$

47,5

57,5
78

78
91,5

94
95

101,5

110,5

120,5

129
140,5

140,5
150,5

160,5

173

180,5

192
200,5

210,5

220,5

230,5

245,5

260,5

270,5

280,5

290,5

300,5

313,5

320,5

340,5

350,5

364,5

370,5

378,5

400,5

400,5
412
440,5
$289-1,44$

$537-1,49$
$-2,04$

$-1,81$

$-1,67$

$-1,36$

$-$

$-$

$-0,71$
0,20

$-0,27$

$-0,56$

$-0,59$

$-0,03$

$-0,59$

$-0,86$

$-0,85$

$-1,01$

$-0,73$

$-1,24$

$-0,94$

$-1,13$

$-1,11$

$-1,28$

$-0,88$

$-1,32$

$-1,05$

$-1,42$

$-1,25$

$-1,50$

$-1,58$

$-1,78$

$-1,94$

$-$

$-2,24$
64,0

69,8

72,1

77,7

79,0

82,0

85,9

87,8

89,5

91,5

95,5

99,2

108,1

111,0

111,2

118,3

118,5

122,2

128,0

130,5

137,0

139,5

141,8

$\begin{array}{lr}50,1 & 141,8 \\ - & 1,0\end{array}$

74,1

75,6

2,1

3,0
3,8

4,4

70,0
76,1

$-$

42,5

41,2

9,0

9,6
9,8

12,4

27,0

34,0

40,0

48,0

55,0

57,8

61,4

63,5

66,8

69,2

72,1

74,9

77,7

82,0

85,5

87,9

90,3

92,6

$\begin{array}{ll}68,0 & 95,0 \\ 64,2 & 98,0\end{array}$

$67,6 \quad 99,7$

- $\quad 104,4$

106,8

$72,4 \quad 110,1$

- $\quad 111,5$

77,1

$77,2 \quad 121,3$

$81,0 \quad 128,0$

(continued on next page) 
Appendix (continued)

\begin{tabular}{|c|c|c|c|c|}
\hline Core & $\begin{array}{l}\text { Depth } \\
\text { (cmbsf) }\end{array}$ & $\begin{array}{l}\delta^{18} \mathrm{O} \\
\text { (per mille) }\end{array}$ & $\begin{array}{l}\text { MAR Aragonite } \\
\left(\mathrm{g} \cdot \mathrm{cm}^{-2} \cdot \mathrm{kyr}^{-1}\right)\end{array}$ & $\begin{array}{l}\text { Calendar Age } \\
\text { (cal kyr BP) }\end{array}$ \\
\hline P7102-14 & 450,5 & $-1,77$ & - & 129,7 \\
\hline P7102-14 & 465 & - & 73,1 & 132,2 \\
\hline P7102-14 & 474,5 & $-1,61$ & 66,2 & 133,9 \\
\hline P7102-14 & 484,5 & $-0,27$ & 42,1 & 135,6 \\
\hline P7102-14 & 494,5 & 0,08 & 48,0 & 137,3 \\
\hline P7102-14 & 505 & - & 42,0 & 139,1 \\
\hline P7102-14 & 510,5 & $-0,04$ & - & 140,1 \\
\hline P7102-14 & 514 & - & 44,0 & 140,7 \\
\hline P7102-14 & 520,5 & 0,33 & - & 141,8 \\
\hline P7102-14 & 524 & - & 53,0 & 141,8 \\
\hline P7102-14 & 530,5 & $-0,14$ & 63,9 & 143,0 \\
\hline P7102-14 & 545,5 & $-0,10$ & 51,0 & 145,0 \\
\hline P7102-14 & 550 & - & 54,8 & - \\
\hline CH0288-108 & 0 & $-2,01$ & - & 0,0 \\
\hline CH0288-108 & 10 & $-2,03$ & - & 3,0 \\
\hline CH0288-108 & 20 & $-2,04$ & - & 6,0 \\
\hline CH0288-108 & 30 & $-1,83$ & - & 9,0 \\
\hline CH0288-108 & 40 & $-1,92$ & - & 12,0 \\
\hline CH0288-108 & 50 & $-1,12$ & - & 15,0 \\
\hline CH0288-108 & 60 & $-0,49$ & - & 18,0 \\
\hline CH0288-108 & 70 & 0,10 & - & 21,0 \\
\hline CH0288-108 & 80 & 0,05 & - & 24,0 \\
\hline CH0288-108 & 90 & 0,10 & - & 27,0 \\
\hline CH0288-108 & 100 & $-0,30$ & - & 32,0 \\
\hline CH0288-108 & 110 & $-0,39$ & - & 37,0 \\
\hline CH0288-108 & 120 & $-0,49$ & - & 42,0 \\
\hline CH0288-108 & 142 & $-0,52$ & - & 53,0 \\
\hline CH0288-108 & 150 & $-0,70$ & - & 57,0 \\
\hline CH0288-108 & 160 & $-0,24$ & - & 62,0 \\
\hline CH0288-108 & 170 & $-0,61$ & - & 64,2 \\
\hline CH0288-108 & 187 & $-0,81$ & - & 68,0 \\
\hline CH0288-108 & 190 & $-0,85$ & - & 68,7 \\
\hline CH0288-108 & 240 & $-1,37$ & - & 79,8 \\
\hline CH0288-108 & 250 & $-1,45$ & - & 82,0 \\
\hline CH0288-108 & 260 & $-1,31$ & - & 84,6 \\
\hline CH0288-108 & 268 & $-1,02$ & - & 86,6 \\
\hline CH0288-108 & 280 & $-0,96$ & - & 89,7 \\
\hline CH0288-108 & 290 & $-1,50$ & - & 92,2 \\
\hline CH0288-108 & 310 & $-1,42$ & - & 97,3 \\
\hline CH0288-108 & 318 & $-1,03$ & - & 99,4 \\
\hline CH0288-108 & 340 & $-1,24$ & - & 105,0 \\
\hline CH0288-108 & 359 & $-1,06$ & - & 109,9 \\
\hline CH0288-108 & 364 & $-1,27$ & - & 111,1 \\
\hline CH0288-108 & 372 & $-1,00$ & - & 113,2 \\
\hline CH0288-108 & 380 & $-1,26$ & - & 115,2 \\
\hline CH0288-108 & 390 & $-1,59$ & - & 117,8 \\
\hline CH0288-108 & 401 & $-1,71$ & - & 120,6 \\
\hline CH0288-108 & 410 & $-2,01$ & - & 122,9 \\
\hline CH0288-108 & 420 & $-2,18$ & - & 125,4 \\
\hline CH0288-108 & 430 & $-2,27$ & - & 128,0 \\
\hline CH0288-108 & 440 & $-1,68$ & - & 129,1 \\
\hline CH0288-108 & 490 & $-1,58$ & - & 134,5 \\
\hline CH0288-108 & 500 & $-0,05$ & - & 135,6 \\
\hline MD03-2632 & 510 & 0,21 & - & 136,7 \\
\hline MD03-2632 & 520 & $-0,04$ & - & 137,8 \\
\hline MD03-2632 & 530 & 0,19 & - & 138,9 \\
\hline MD03-2632 & 540 & 0,28 & - & 141,8 \\
\hline MD03-2632 & 550 & $-0,32$ & - & 150,4 \\
\hline MD03-2632 & 562 & $-0,52$ & - & 160,8 \\
\hline MD03-2632 & 570 & $-0,37$ & - & 167,7 \\
\hline MD03-2632 & 580 & $-0,42$ & - & 176,4 \\
\hline MD03-2632 & 590 & $-0,07$ & - & 185,0 \\
\hline MD03-2632 & 600 & $-0,18$ & - & 186,6 \\
\hline MD03-2632 & 610 & $-0,84$ & - & 188,1 \\
\hline MD03-2632 & 620 & $-1,26$ & - & 189,7 \\
\hline MD03-2632 & 628 & $-1,12$ & - & 190,9 \\
\hline MD03-2632 & 680 & $-1,45$ & - & 199,0 \\
\hline MD03-2632 & 690 & $-1,38$ & - & 200,4 \\
\hline MD03-2632 & 700 & $-1,28$ & - & 201,8 \\
\hline MD03-2632 & 710 & $-1,18$ & - & 203,2 \\
\hline MD03-2632 & 718 & $-1,27$ & - & 204,4 \\
\hline MD03-2632 & 800 & $-1,49$ & - & 215,9 \\
\hline MD03-2632 & 820 & $-1,51$ & - & 218,8 \\
\hline MD03-2632 & 830 & $-1,49$ & - & 220,2 \\
\hline
\end{tabular}

Appendix (continued)

\begin{tabular}{|c|c|c|c|c|}
\hline Core & $\begin{array}{l}\text { Depth } \\
\text { (cmbsf) }\end{array}$ & $\begin{array}{l}\delta^{18} \mathrm{O} \\
\text { (per mille) }\end{array}$ & $\begin{array}{l}\text { MAR Aragonite } \\
\left(\mathrm{g} \cdot \mathrm{cm}^{-2} \cdot \mathrm{kyr}^{-1}\right)\end{array}$ & $\begin{array}{l}\text { Calendar Age } \\
\text { (cal kyr BP) }\end{array}$ \\
\hline MD03-2632 & 840 & $-0,60$ & - & 221,6 \\
\hline MD03-2632 & 850 & $-0,39$ & - & 223,0 \\
\hline MD03-2632 & 860 & $-0,80$ & - & 227,8 \\
\hline MD03-2632 & 870 & $-1,37$ & - & 232,5 \\
\hline MD03-2632 & 880 & $-1,67$ & - & 237,3 \\
\hline MD03-2632 & 890 & $-2,01$ & - & 242,0 \\
\hline MD03-2632 & 900 & $-1,26$ & - & 243,4 \\
\hline MD03-2632 & 910 & $-0,21$ & - & 244,9 \\
\hline MD03-2632 & 920 & $-0,18$ & - & 246,3 \\
\hline MD03-2632 & 925 & $-1,16$ & - & 247,0 \\
\hline MD03-2632 & 960 & 0,02 & - & 252,0 \\
\hline MD03-2632 & 970 & $-0,10$ & - & 259,8 \\
\hline MD03-2632 & 980 & $-0,23$ & - & 267,6 \\
\hline MD03-2632 & 990 & $-0,16$ & - & 275,4 \\
\hline MD03-2632 & 1000 & 0,00 & - & 283,2 \\
\hline MD03-2632 & 1010 & $-0,76$ & - & 291,0 \\
\hline MD03-2632 & 1020 & $-0,64$ & - & 292,3 \\
\hline MD03-2632 & 1030 & $-0,61$ & - & 293,7 \\
\hline MD03-2632 & 1040 & $-0,63$ & - & 295,0 \\
\hline MD03-2632 & 1050 & $-0,38$ & - & 296,3 \\
\hline MD03-2632 & 1060 & $-0,50$ & - & 297,7 \\
\hline MD03-2632 & 1082 & $-0,81$ & - & 300,6 \\
\hline MD03-2632 & 1088 & $-0,99$ & - & 301,4 \\
\hline MD03-2632 & 1144 & $-1,12$ & - & 308,9 \\
\hline MD03-2632 & 1150 & $-1,05$ & - & 309,7 \\
\hline MD03-2632 & 1160 & $-1,15$ & - & 311,0 \\
\hline MD03-2632 & 1170 & $-0,97$ & - & 312,3 \\
\hline MD03-2632 & 1180 & $-1,10$ & - & 313,7 \\
\hline MD03-2632 & 1213 & $-1,16$ & - & 318,1 \\
\hline MD03-2632 & 1220 & $-0,80$ & - & 319,0 \\
\hline MD03-2632 & 1230 & $-1,52$ & - & 321,8 \\
\hline MD03-2632 & 1250 & $-1,00$ & - & 327,3 \\
\hline MD03-2632 & 1260 & $-1,19$ & - & 330,1 \\
\hline MD03-2632 & 1283 & $-1,49$ & - & 336,4 \\
\hline MD03-2632 & 1290 & $-1,55$ & - & 337,4 \\
\hline MD03-2632 & 1300 & $-1,21$ & - & 338,1 \\
\hline MD03-2632 & 1310 & $-0,17$ & - & 338,8 \\
\hline MD03-2632 & 1395 & 0,22 & - & 345,0 \\
\hline MD03-2632 & 1400 & 0,06 & - & 346,1 \\
\hline MD03-2632 & 1410 & $-0,05$ & - & 348,4 \\
\hline MD03-2632 & 1430 & $-0,15$ & - & 352,8 \\
\hline MD03-2632 & 1440 & $-0,20$ & - & 355,1 \\
\hline MD03-2632 & 1450 & 0,13 & - & 357,3 \\
\hline MD03-2632 & 1460 & 0,01 & - & 359,6 \\
\hline MD03-2632 & 1493 & $-0,76$ & - & 366,9 \\
\hline MD03-2632 & 1500 & $-0,77$ & - & 368,5 \\
\hline MD03-2632 & 1510 & $-0,45$ & - & 370,7 \\
\hline MD03-2632 & 1520 & $-0,62$ & - & 373,0 \\
\hline MD03-2632 & 1530 & $-0,59$ & - & 375,2 \\
\hline MD03-2632 & 1540 & $-1,02$ & - & 377,5 \\
\hline MD03-2632 & 1550 & $-0,75$ & - & 379,7 \\
\hline MD03-2632 & 1561 & $-1,21$ & - & 382,2 \\
\hline MD03-2632 & 1596 & $-0,99$ & - & 390,0 \\
\hline MD03-2632 & 1600 & $-1,05$ & - & 391,1 \\
\hline MD03-2632 & 1610 & $-1,43$ & - & 393,7 \\
\hline MD03-2632 & 1620 & $-1,20$ & - & 396,4 \\
\hline MD03-2632 & 1720 & $-1,48$ & - & 423,0 \\
\hline MD03-2632 & 1730 & $-1,60$ & - & 424,6 \\
\hline MD03-2632 & 1740 & $-1,49$ & - & 426,1 \\
\hline MD03-2632 & 1750 & $-1,44$ & - & 427,7 \\
\hline MD03-2632 & 1760 & $-1,47$ & - & 429,2 \\
\hline MD03-2632 & 1770 & 0,10 & - & 430,8 \\
\hline MD03-2632 & 1780 & $-0,31$ & - & 432,3 \\
\hline MD03-2632 & 1790 & $-0,02$ & - & 433,9 \\
\hline MD03-2632 & 1800 & 0,45 & - & 435,4 \\
\hline MD03-2632 & 1810 & 0,48 & - & 437,0 \\
\hline
\end{tabular}

\section{References}

Alley, R.B., Clark, P.U., Huybrechts, P., Joughin, I., 2005. Ice-sheet and sea-level changes. Science 310, 456-460.

Alley, R.B., Marotzke, J., Nordhaus, W.D., Overpeck, J.T., Peteet, D.M., Pielke, R.A. Pierrehumbert, R.T., Rhines, P.B., Stocker, T.F., Talley, L.D., Wallace, J.M., 2003. Abrupt climate change. Science 299, 2005-2010. 
Andresen, N., Reijmer, J.J.G., Droxler, A.W., 2003. Timing and distribution of calciturbidites around a deeply submerged carbonate platform in a seismically active setting (Pedro Bank, Northern Nicaragua Rise, Caribbean Sea). International Journal of Earth Sciences 92, 573-592.

Arden, D.D., 1975. Geology of Jamaica and the Nicaragua Rise. In: Nairn, A.E.M. Stehli, F.G. (Eds.), The Ocean Basins and Margins. The Gulf of Mexico and the Caribbean, vol. 3. Plenum Press, New York, pp. 617-661.

Atkinson, L.P., Berger, T., Hamilton, P., Waddell, E., Leaman, K., Lee, T.N., 1995 Current-Meter observations in the Old-Bahama Channel. Journal of Geophysical Research-Oceans 100, 8555-8560.

Bard, E., Hamelin, B., Fairbanks, R.G., Zindler, A., 1990. Calibration of the C-14 Timescale over the Past 30,000 Years using mass-spectrometric U-Th ages from Barbados Corals. Nature 345, 405-410.

Bintanja, R., van de Wal, R.S.W., Oerlemans, J., 2005. Modelled atmospheric temperatures and global sea levels over the past million years. Nature 437 $125-128$

Boss, S.K., Rasmussen, K.A., 1995. Misuse of Fischer Plots as Sea-Level Curves. Geology 23, 221-224.

Brunskill, G.J., Woolfe, K.J., Zagorskis, I., 1995. Distribution of riverine sediment chemistry on the shelf, slope and rise of the Gulf of Papua. Geo Marine Letters $15,160-165$

Camoin, G.F., Montaggioni, L.F., Braithwaite, C.J.R., 2004. Late glacial to post glacial sea levels in the Western Indian Ocean. Marine Geology 206, 119-146.

Carew, J.L., Mylroie, J.E., 1985. Pleistocene and Holocene stratigraphy of San Salvador Island, Bahamas, with reference to marine and terrestrial lithofacies at French Bay. In: Curran, H.A. (Ed.), Pleistocene and Holocene Environments on San Salvador Island, Bahamas. CCFL Bahamian Field Station, Fort Lauderdale, Florida, pp. $11-61$

Carew, J.L., Mylroie, J.E., 1995. Quaternary Tectonic Stability of the Bahamian Archipelago - evidence from Fossil Coral-Reefs and Flank Margin Caves. Quaternary Science Reviews 14, 145-153.

Carson, B.E., Francis, J.M., Leckie, R.M., Droxler, A.W., Dickens, G.R., Jorry, S.J. Bentley, S.J., Peterson, L.C., Opdyke, B.N., 2008. Benthic Foraminiferal response to sea level change in the mixed siliciclastic-carbonate system of southern Ashmore Trough (Gulf of Papua). Journal of Geophysical Research-Earth Surface 113, F01S20, doi:10.1029/2006JF000629.

Cheng, H., Edwards, R.L., Broecker, W.S., Denton, G.H., Kong, X.G., Wang, Y.J., Zhang, R., Wang, X.F., 2009. Ice age terminations. Science 326, 248-252.

Clark, P.U., Dyke, A.S., Shakun, J.D., Carlson, A.E., Clark, J., Wohlfarth, B., Mitrovica, J.X. Hostetler, S.W., McCabe, A.M., 2009. The Last Glacial Maximum. Science 325 710-714

Clark, P.U., Marshall McCabe, A., Mix, A.C., Weaver, A.J., 2004. Rapid rise of sea leve 19,000 years ago and its global implications. Science 304, 1141-1144.

Cunningham, A.D., 1998. The Neogene Evolution of the Pedro Channel Carbonate System, Northern Nicaragua Rise. Ph.D. Thesis, Rice University, Houston.

Cutler, K.B., Edwards, R.L., Taylor, F.W., Cheng, H., Adkins, J., Gallup, C.D., Cutler, P.M. Burr, G.S., Bloom, A.L., 2003. Rapid sea-level fall and deep-ocean temperature change since the last interglacial period. Earth and Planetary Science Letters 206, 253-271.

Daugherty, D.R., Boardman, M.R., Metzler, C.V., 1987. Characteristics and origins of joints and sedimentary dikes of the Bahama Islands. In: Proceedings of the 3rd Symposium on the Geology of the Bahamas, pp. 45-56.

Dolan, P., 1972. Genesis and distribution of recent sediments on the Pedro Bank south of Jamaica. Ph.D. Thesis, University College, London.

Droxler, A.W. 1984. Later Quaternary glacial cycles in the Bahamian deep basins and in the adjacent Atlantic Ocean. Ph.D. Thesis, University of Miami, Coral Gables.

Droxler, A.W., Schlager, W., 1985. Glacial versus interglacial sedimentation rates and turbidite frequency in the Bahamas. Geology 13, 799-802.

Droxler, A.W., Schlager, W., Whallon, C.C., 1983. Quaternary aragonite cycles and oxygen isotope record in bahamian carbonate ooze. Geology 11, 235-239.

Dullo, W.C., 1997. Die Plattformhangmorphologie der Pedro Bank in der Karibik. Geol Bl NO-Bayern 47, 303-320.

Duncan, D.S., Hine, A.C., Droxler, A.W., 1999. Tectonic controls on carbonate sequence formation in an active strike-slip setting: Serranilla Basin, Northern Nicaragua Rise, Western Caribbean Sea. Marine Geology 160, 355-382.

Dutton, A., Bard, E., Antonioli, F., Esat, T.M., Lambeck, K., McCulloch, M.T., 2009. Phasing and amplitude of sea-level and climate change during the penultimate interglacial. Nature Geoscience 2, 355-359.

Edwards, R.L., Beck, J.W., Burr, G.S., Donahue, D.J., Chappell, J.M.A., Bloom, A.L. Druffel, E.R.M., Taylor, F.W., 1993. A Large Drop in Atmospheric C-14/C-12 an Reduced Melting in the Younger Dryas, Documented with Th-230 Ages of Corals. Science 260, 962-968.

Emiliani, C. 1955. Pleistocene temperatures. Journal of Geology 63, 538-578.

Esat, T.M., McCulloch, M.T., Chappell, J., Pillans, B., Omura, A., 1999. Rapid fluctuations in sea level recorded at Huon Peninsula during the penultimate deglaciation. Science 283, 197-201.

Fairbanks, R.G., 1989. A 17,000-Year Glacio-Eustatic Sea-Level Record - Influence of Glacial Melting Rates on the Younger Dryas Event and Deep-Ocean Circulation. Nature 342, 637-642.

Francis, J.M., 2007. Late Quaternary sediment dispersal and accumulation on slopes of the Great Barrier Reef mixed siliciclastic-carbonate depositional system, Gulf of Papua, Papua New Guinea and north Queensland Margin, Australia. Ph.D. Thesis, Rice University, Houston.

Francis, J.M., Daniell, J.J., Droxler, A.W., Dickens, G.R., Bentley, S.J., Peterson, L.C. Opdyke, B.N., Beaufort, L., 2008. Deep water geomorphology of the mixed siliciclastic-carbonate system, Gulf of Papua. Journal of Geophysical ResearchEarth Surface 113, F01S16, doi:10.1029/2006JF000629.

Gischler, E., 2003. Holocene lagoonal development in the isolated carbonate platforms off Belize. Sedimentary Geology 159, 113-132.

Gischler, E., Lomando, A.J., Hudson, J.H., Holmes, C.W., 2000. Last interglacial reef growth beneath Belize barrier and isolated platform reefs. Geology 28, 387-390.

Glaser, K.S., 1991. Late Quaternary periplatform sediments and environments on the Northeastern Nicaragua Rise, Caribbean Sea. Ph.D. Thesis, Rice University, Houston.

Glaser, K.S., Droxler, A.W., 1991. High production and highstand shedding from deeply submerged carbonate banks, Northern Nicaragua Rise. Journal of Sedimentary Petrology 61, 128-142.

Glaser, K.S., Droxler, A.W., 1993. Controls and development of Late Quaternary periplatform carbonate stratigraphy in Walton Basin (Northeastern Nicaragua Rise, Caribbean Sea). Paleoceanography 8, 243-274.

Haak, A.B., Schlager, W., 1989. Compositional Variations in Calciturbidites Due to Sea-Level Fluctuations, Late Quaternary, Bahamas. Geologische Rundschau 78, 477-486.

Hallock, P., Hine, A.C., Vargo, G.A., Elrod, J.A., Jaap, W.C., 1988. Platforms of the Nicaraguan rise - examples of the sensitivity of carbonate sedimentation to excess Trophic Resources. Geology 16, 1104-1107.

Hanebuth, T., Stattegger, K., Grootes, P.M., 2000. Rapid flooding of the Sunda Shelf: A late-glacial sea-level record. Science 288, 1033-1035.

Harris, P.T., Baker, E.K., Cole, A.R., Short, S.A., 1993. A Preliminary-Study of Sedimentation in the Tidally Dominated Fly River Delta, Gulf of Papua. Continental Shelf Research 13, 441-472.

Hathearn, W.D., 1963. Bathymetry of the Straits of Florida and the Bahamas Islands, 2) Bathymetry of the Tongue of the Ocean, Bahamas. Bulletin of Marine Sciences 13, 365-377.

Hearty, P.J., Kindler, P., 1993. New Perspectives on Bahamian Geology - San-Salvador Island, Bahamas. Journal of Coastal Research 9, 577-594.

Hine, A.C., Hallock, P., Harris, M.W., Mullins, H.T., Belknap, D.F., Jaap, W.C., 1988. Halimeda Bioherms Along an Open Seaway - Miskito Channel, Nicaraguan Rise, Sw Caribbean Sea. Coral Reefs 6, 173-178.

Hine, A.C., Mullins, H.T., 1981. Modern Carbonate Shelf-Slope Boundaries. Aapg Bulletin-American Association of Petroleum Geologists 65, 938-939.

Holcombe, T.L., Ladd, J.W., Westbrook, G., Edgar, N.T., Bowland, C.L., 1990. Caribbean marine geology; ridges and basins of the plate interior. In: Dengo, G., Case, J.E. (Eds.), The Caribbean Region. Geological Society of America, Boulder, pp. 231-260.

Holcombe, T.L., Vogt, P.R., Matthews, J.E., Murchison, R.R., 1973. Evidence for sea floor spreading in the Cayman Trough. Earth \& Planetary Science Letters 20, 357-371.

Horsfield, W.T., 1975. Quaternary Vertical Movements in Greater Antilles. Geological Society of America Bulletin 86, 933-938.

Hughen, K.A., Baillie, M.G.L., Bard, E., Beck, J.W., Bertrand, C.J.H., Blackwell, P.G., Buck, C.E., Burr, G.S., Cutler, K.B., Damon, P.E., Edwards, R.L., Fairbanks, R.G., Friedrich, M., Guilderson, T.P., Kromer, B., McCormac, G., Manning, S., Ramsey, C.B., Reimer, P.J., Reimer, R.W., Remmele, S., Southon, J.R., Stuiver, M., Talamo, S., Taylor, F.W., van der Plicht, J., Weyhenmeyer, C.E., 2004. Marine04 Marine Radiocarbon Age Calibration, 0-26 cal kyr BP. Radiocarbon 46, 1059-1086.

Husseini, S.I., Matthews, R.K., 1972. Distribution of high-magnesium calcite in lime muds of the Great Bahama Bank; diagenetic implications. Journal of Sedimentary Petrology 42, 179-182.

Jorry, S.J., Droxler, A.W., Mallarino, G., Dickens, G.R., Bentley, S.J., Beaufort, L., Peterson, L.C., Opdyke, B.N., 2008. Bundled turbidite deposition in the central Pandora Trough (Gulf of Papua) since Last Glacial Maximum: Linking sediment nature and accumulation to sea level fluctuations at millennial timescale. Journal of Geophysical Research-Earth Surface 113, F01S19, doi:10.1029/ 2006JF000649.

Kinder, T.H., Heburn, G.W., Green, A.W., 1985. Some Aspects of the Caribbean Circulation. Marine Geology 68, 25-52.

Lambeck, K., Chappell, J., 2001. Sea level change through the last glacial cycle. Science 292, 679-686.

Lantzsch, H., Roth, S., Reijmer, J.J.G., Kinkel, H., 2007. Sea-level related resedimentation processes on the northern slope of Little Bahama Bank (Middle Pleistocene to Holocene). Sedimentology 54, 1307-1322.

Lea, D.W. Martin, P.A., Pak, D.K., Spero, H.J. 2002. Reconstructing a 350 ky history of sea level using planktonic $\mathrm{Mg} / \mathrm{Ca}$ and oxygen isotope records from a Cocos Ridge core. Quaternary Science Reviews 21, 283-293.

Leaman, K.D. Vertes, PS, Atkinson, LP. Lee, TN , Hamilton, P. Waddell, E, 1995. Transport, Potential Vorticity, and Current Temperature Structure across Northwest Providence and Santaren Channels and the Florida Current Off Cay-Sal Bank. Journal of Geophysical Research-Oceans 100, 8561-8569.

Lebreiro, S.M., Voelker, A.H.L., Vizcaino, A., Abrantes, F.G., Alt-Epping, U., Jung, S., Thouveny, N., Gracia, E., 2009. Sediment instability on the Portuguese continental margin under abrupt glacial climate changes (last $60 \mathrm{kyr}$ ). Quaternary Science Reviews 28, 3211-3223.

Leroy, S., deLepinay, B.M., Mauffret, A., Pubellier, M., 1996. Structural and tectonic evolution of the eastern Cayman Trough (Caribbean sea) from seismic reflection data. Aapg Bulletin-American Association of Petroleum Geologists 80, 222-247.

Lisiecki, L.E., Raymo, M.E., 2005. A Pliocene-Pleistocene stack of 57 globally distributed benthic delta O-18 records. Paleoceanography 20. 
MacKinnon, L., Jones, B., 2001. Sedimentological evolution of North Sound, Grand Cayman - a freshwater to marine carbonate succession driven by Holocene sea-level rise. Journal of Sedimentary Research 71, 568-580.

Malone, M.J., Slowey, N.C., Henderson, G.M., 2001. Early diagenesis of shallow-water periplatform carbonate sediments, leeward margin, Great Bahama Bank (Ocean Drilling Program Leg 166). Geological Society of America Bulletin 113, 881-894.

Mann, P., Burke, K., 1990. Transverse Intraarc Rifting - Paleogene Wagwater Belt, Jamaica. Marine and Petroleum Geology 7, 410.

Milliman, J.D., 1974. Marine Carbonates. Springer Verlag, Berlin, Heidelberg, New York.

Milliman, J.D., 1995. Sediment discharge to the ocean from small mountainous rivers: the New Guinea example. Geo-Marine Letters 15, 127-133.

Milliman, J.D., Freile, D., Steinen, R.P., Wilber, R.J., 1993. Great Bahama Bank Aragonitic Muds - Mostly Inorganically Precipitated, Mostly Exported. Journal of Sedimentary Petrology 63, 589-595.

Muhammad, Z., Bentley, S.J., Febo, L.A., Droxler, A.W., Dickens, G.R., Peterson, L.C. Opdyke, B.N., 2008. Excess Pb-210 inventories and fluxes along the continental slope and basins of the Gulf of Papua. Journal of Geophysical Research-Earth Surface 113, F01S17, doi:10.1029/2006JF000629.

Mullins, H.T., Heath, K.C., Vanburen, H.M., Newton, C.R., 1984. Anatomy of a Modern Open-Ocean Carbonate Slope - Northern Little Bahama Bank. Sedimentology 31, 141-168.

Mutti, M., Droxler, A.W., Cunningham, A.D., 2005. Evolution of the Northern Nicaragua Rise during the Oligocene-Miocene: drowning by environmental factors. Sedimentary Geology 175, 237-258.

Perfit, M.R., Heezen, B.C., 1978. Geology and Evolution of Cayman Trench. Geological Society of America Bulletin 89, 1155-1174.

Pickard, G.L., Donguy, J.R., Henin, C., Rougerie, R., 1977. A review of the physical oceanography of the Great Barrier Reef and Western Coral Sea. Aust. Inst. of Mar. Sci. Cape Ferguson.

Pierau, R., Hanebuth, T.J.J., Krastel, S., Henrich, R., 2010. Late Quaternary climatic events and sea-level changes recorded by turbidite activity, Dakar Canyon, NW Africa. Quaternary Research 73, 385-392.

Pindell, J.L., Barrett, S.F., 1990. Geological evolution of the Caribbean region: a plate tectonic perspective. In: Dengo, G., Case, J.E. (Eds.), The Caribbean Region. Geological Society of America, Boulder, pp. 405-432.

Purdy, E.G., 1963. Recent calcium carbonate facies of the Great Bahama Bank. 1. Petrography and reaction groups. Journal of Geology 71, 334-355.

Purdy, E.G., 1974. Reef configurations, cause and effect. In: Laporte, L.F. (Ed.), Reefs in Time and Space. SEPM Special Publication, Tulsa, pp. 9-76.

Reijmer, J.J., Swart, P.K., Bauch, T., Otto, R., Reuning, L., Roth, S., Zechel, S., 2009. A reevaluation of facies variations on Great Bahama Bank 1: New Facies Maps of Western Great Bahama Bank. In: Swart, P.K., Eberli, G.P., McKenzie, J.A. (Eds.), Perspectives in Sedimentary Geology: A Tribute to the Career of Robert Nathan Ginsburg. International Association of Sedimentologists Special Publication, pp. 29-46.

Reijmer, J.J.G., Andresen, N., 2007. Mineralogy and grain size variations along two carbonate margin-to-basin transects (Pedro Bank, Northern Nicaragua Rise). Sedimentary Geology 198, 327-350.

Reimer, P.J., Reimer, R.W., 2001. A marine reservoir correction database and on-line interface Radiocarbon 43, 461-463.

Roberts, H.H., Murray, S.P., 1983. Controls on reef development and the terrigeneous-carbonate interface on a shallow shelf, Nicaragua (Central America). Coral Reefs 2, 71-80.

Rohling, E.J., Grant, K., Bolshaw, M., Roberts, A.P., Siddall, M., Hemleben, C., Kucera, M., 2009. Antarctic temperature and global sea level closely coupled over the past five glacial cycles. Nature Geoscience 2, 500-504.

Rohling, E.J., Grant, K., Hemleben, C., Siddall, M., Hoogakker, B.A.A., Bolshaw, M., Kucera, M., 2008. High rates of sea-level rise during the last interglacial period. Nature Geoscience 1, 38-42.

Rosencrantz, E., Ross, M.I., Sclater, J.G., 1988. Age and Spreading History of the Cayman Trough as Determined from Depth, Heat-Flow, and Magnetic-Anomalies. Journal of Geophysical Research-Solid Earth and Planets 93, 2141-2157.

Rosencrantz, E., Sclater, J.G., 1986. Depth and Age in the Cayman Trough. Earth and Planetary Science Letters 79, 133-144.

Schlager, W., Reijmer, J.J.G., Droxler, A.W., 1994. Highstand shedding of carbonate platforms. Journal of Sedimentary Research 64, 270-281.

Schmitz, W.J., Richardson, P.L., 1991. On the Sources of the Florida Current. Deep-Sea Research Part a-Oceanographic Research Papers 38, S379-S409.

Sepulcre, S., Tachikawa, K., Vidal, L., Thouveny, N., Bard, E., 2009. Preservation state of metastable magnesian calcite in periplatform sediments from the Caribbean Sea over the last million years. Geochemistry Geophysics Geosystems 10
Shackleton, N.J., Opdyke, N.D., 1977. Oxygen Isotope and Paleomagnetic Evidence for Early Northern Hemisphere Glaciation. Nature 270, 216-219.

Siddall, M., Bard, E., Rohling, E.J., Hemleben, C., 2006. Sea-level reversal during Termination II. Geology 34, 817-820.

Siddall, M., Rohling, E.J., Almogi-Labin, A., Hemleben, C., Meischner, D., Schmelzer, I. Smeed, D.A., 2003. Sea-level fluctuations during the last glacial cycle. Nature 423, 853-858.

Skene, K.I., Piper, D.J.W., 2003. Late Quaternary stratigraphy of Laurentian Fan: a record of events off the eastern Canadian continental margin during the last deglacial period. Quaternary International 99, 135-152.

Slingerland, R., Selover, R.W., Ogston, A.S., Keen, T.R., Driscoll, N.W., Milliman, J.D. 2008. Building the Holocene clinothem in the Gulf of Papua: An ocean circulation study. Journal of Geophysical Research-Earth Surface 113, F01S14, doi:10. 1029/2006JF000629.

Slowey, N.C., Wilber, R.J., Haddad, G.A., Henderson, G.M., 2002. Glacial-to-Holocene sedimentation on the western slope of Great Bahama Bank. Marine Geology $185,165-176$.

Stuiver, M., Reimer, P.J., 1993. Extended ${ }^{14} \mathrm{C}$ data base and revised CALIB radiocarbon calibration program. Radiocarbon 35, 215-230.

Stuiver, M., Reimer, P.J., Reimer, R.W., 2005. CALIB 5.0. WWW program and documentation.

Tcherepanov, E.N., Droxler, A.W., Lapointe, P., Mohn, K., 2008. Carbonate seismic stratigraphy of the Gulf of Papua mixed depositional system: Neogene stratigraphic signature and eustatic control. Basin Research 20, 185-209.

Thierstein, H.R., Geitzenauer, K.R., Molfino, B., 1977. Global Synchroneity of Late Quaternary Coccolith Datum levels - validation by oxygen isotopes. Geology 5 , 400-404.

Thompson, P.R., Be, A.W.H., Duplessy, J.C., Shackleton, N.J., 1979. Disappearance of Pink-Pigmented Globigerinoides-Ruber at $120,000-\mathrm{Yr} \mathrm{Bp}$ in the Indian and Pacific Oceans. Nature 280, 554-558.

Thompson, W.G., Goldstein, S.L., 2005. Open-system coral ages reveal persistent suborbital sea-level cycles. Science 308, 401-404.

Thompson, W.G., Goldstein, S.L., 2006. A radiometric calibration of the SPECMAP timescale. Quaternary Science Reviews 25, 3207-3215.

Toucanne, S., Zaragosi, S., Bourillet, J.F., Naughton, F., Cremer, M., Eynaud, F. Dennielou, B., 2008. Activity of the turbidite levees of the Celtic-Armorican margin (Bay of Biscay) during the last 30,000 years: Imprints of the last European deglaciation and Heinrich events. Marine Geology 247, 84-103.

Triffleman, N.J., 1989. Morphology, sediments and depositional environments of a partially drowned carbonate platform: Serranilla Bank - Southwest Carribbean Sea M.S. Thesis, Univ of South Florida, Tampa.

Triffleman, N.J., Hallock, P., Hine, A.C., 1992. Morphology, Sediments, and Depositional-Environments of a Small Carbonate Platform - Serranilla Bank, Nicaraguan Rise, Southwest Caribbean Sea. Journal of Sedimentary Petrology 62 591-606

Wajsowicz, R.C., 2002. A modified Sverdrup model of the Atlantic and Caribbean circulation. Journal of Physical Oceanography 32, 973-993.

Walker, L.N., Mylroie, J.E., Walker, A.D., Mylroie, J.R., 2008. The Caves of Abaco Island, Bahamas: keys to geologic timelines. Journal of Cave and Karst Studies 70, 108-119.

Walsh, J.P., Nittrouer, C.A., 2003. Contrasting styles of off-shelf sediment accumulation in New Guinea. Marine Geology 196, 105-125.

Weaver, A.J., Saenko, O.A., Clark, P.U., Mitrovica, J.X., 2003. Meltwater pulse 1A from Antarctica as a trigger of the bolling-allerod warm interval. Science 299 1709-1713

Webster, J., 2006., personal communication.

Wilber, R.J., Milliman, J.D., Halley, R.B., 1990. Accumulation of Bank-Top Sediment on the Western Slope of Great Bahama Bank - Rapid Progradation of a Carbonate Megabank. Geology 18, 970-974.

Wilson, P.A., Roberts, H.H., 1995. Density Cascading - Off-Shelf Sediment Transport Evidence and Implications, Bahama Banks. Journal of Sedimentary Research Section a-Sedimentary Petrology and Processes 65, 45-56.

Wolanski, E., Norro, A., King, B., 1995. Water Circulation in the Gulf of Papua. Continental Shelf Research 15, 185-212.

Wust, G., 1964. Stratification and Circulation in the Antillian-Caribbean Basins. Columbia Univ, Press, New York.

Wyrtki, K., 1962. The subsurface water masses in the western South Pacific Ocean. Australian Journal of Freshwater Research 13, 18-47.

Yokoyama, Y., Lambeck, K., De Deckker, P. Johnston, P., Fifield, I.K., 2000. Timing of the Last Glacial Maximum from observed sea-level minima. Nature 406, 413-416.

Zans, V.A., 1958. The Pedro Cays and Pedro Bank: report of survey of the Cay (1955-1957). Geological Survey of Jamaica, p. 57 